\title{
A History of the Settler-Colonial Freshwater Impure-Ment: Water Pollution and the Creation of Multiple Environmental Injustices Along the Waipā River
}

Water pollution offers significant openings for interrogating what environmental justice (EJ) and injustice means from an Indigenous perspective, and the implications of water pollution on Indigenous peoples' ways of life, values, and sovereign rights. Activist and scholarly literature from Aotearoa suggests there is widespread opposition amongst Māori to the disposal of human waste into water bodies (Broughton et al. 2015; Greensill 2010; Pauling and Ataria 2010). The discharge of wastewater (both treated and untreated) into waterways can be seen as unhealthy, unethical, and a physical and metaphysical attack on Indigenous bodies and their sovereignty. These critiques are embedded in Indigenous sovereignty discourses globally and nationally (concerning Te Tiriti o Waitangi-The Treaty of Waitangi and rangatiratangasovereignty, political authority), as well as Māori ways of seeing the world (premised on understandings of tapu-sacredness and noa-normal, ordinary, safe, not subject to restrictions). The history of the pollution of the Waipā River offers a particularly compelling case of the significance of recognising Māori iwi rangatiratanga, worldview, and values as part of environmental governance and management decision-making processes. 
Māori experiences of environmental (in)justice, therefore, cannot be disconnected from the historic and contemporary injustices of settlercolonialism. Moreover, injustices are often not one single thing (distributive, recognition or procedural) and, therefore, singular interventions that seek to tackle only one driver of injustice are insufficient. Māori experiences of environmental injustices are not simply evidence of distributive inequities, or failure to recognise Māori values, or poorly designed (or deliberately exclusionary) decision-making procedures but are more often a combination of all three. Through an examination of water pollution of the Waipā River, in this chapter, we demonstrate that histories of environmental (in)justices are complex and intertwined with national and local histories, politics, and identities. Injustices, thus, are a product of direct and indirect policies and practices that build up over time (what First Nations scholar Kyle Whyte terms "sedimentation" and “insidious loops”) (Whyte 2018, p. 130).

\section{Water Pollution: An Unacknowledged Problem}

Unlike Te Ao Māori, where steps are taken to avoid polluting water with human waste (as discussed in Chap. 3), water pollution due to the discharge of waste products barely registered as an issue within settler society throughout the nineteenth and early-to-mid-twentieth centuries. Instead attention was firmly fixated on the persistent problems of unruly rivers and unproductive swamps (Knight 2016), with only sporadic reporting of cases (in the early twentieth century) by parliamentarians and communities noting the contamination of waterways due to human activities (most notably mining operations). Throughout this period, towns pumped untreated human waste into waterways and seas, as did factories and farms (effluent mixed with chemicals). Until 1953, there was no specific national legislation nor government policies specifically focused on monitoring and mitigating water pollution (AJHR 1900, 1910, 1925). In 1953, the Water Pollution Act was introduced (Waters Pollution Act 1953) which, as its name suggests, was directed at governing water pollution (New Zealand Parliament 1953). The new act introduced bylaws for industrial waste products and provided for the creation of a new 
institution-the Pollution Advisory Council (PAC) - to prevent and mitigate water pollution throughout the country. The PAC was responsible for designing a national classification system for water quality and the development of by-laws about the disposal of wastewater. Initially, PAC lacked any power to monitor or control water pollution; however, from 1963 the Water Pollution Regulations allowed it to undertake investigations into the drivers and extent of water pollution. In 1956, the PAC released its provisions for acceptable inland and coastal water standards (related to effluent, $\mathrm{pH}$ balances, and minimum water treatment) (Cunningham 2014; Knight 2016).

In 1956, the Department of Health, the Ministry of Works, and the Department of Scientific and Industrial Research prepared a report for PAC on water pollution in the Waikato River catchment. The report was the first substantive environmental study into water pollution in the Waikato River and its tributaries and asserted that no "serious thought was given to [the] pollution problem ... [the rivers and streams] were grossly polluted" (Pollution Advisory Council 1956, p. 1). In regard to the Waipā River and its tributaries, the report found evidence of "serious pollution" in the form of extremely high faecal coliform counts downstream of the townships of Te Kuiti and Otorohanga and poor visual condition of the waterways (see Fig. 5.1) (Pollution Advisory Council 1956 , p. 40). The report noted obvious examples of point source pollution from both townships' sewage systems and industry (specifically the Otorohanga dairy factory). In 1956, for instance, 70 per cent of residents living in Otorohanga district were connected to Otorohanga township's sewage system, which consisted of a single septic tank (capable of handling 110000 gallons daily) that discharged directly into the Waipā River. "Conditions at the outfall" were reported to be "very bad" with large "quantities of paper, rag and fecal matter litter[ing] the river for a long distance downstream" (Pollution Advisory Council 1956, p. 20). Similarly, the two septic tanks, that serviced residents in the township of Te Kuiti (see Fig. 5.2), were observed to be operating ineffectively with the "soapy coloured effluent" staining the banks of the Mangaokewa stream (Pollution Advisory Council 1956, p. 20). Non-point source pollution, such as agricultural run-off, was identified as likely to be the most "widespread source of pollution" in the Waipā catchment, but it was not 


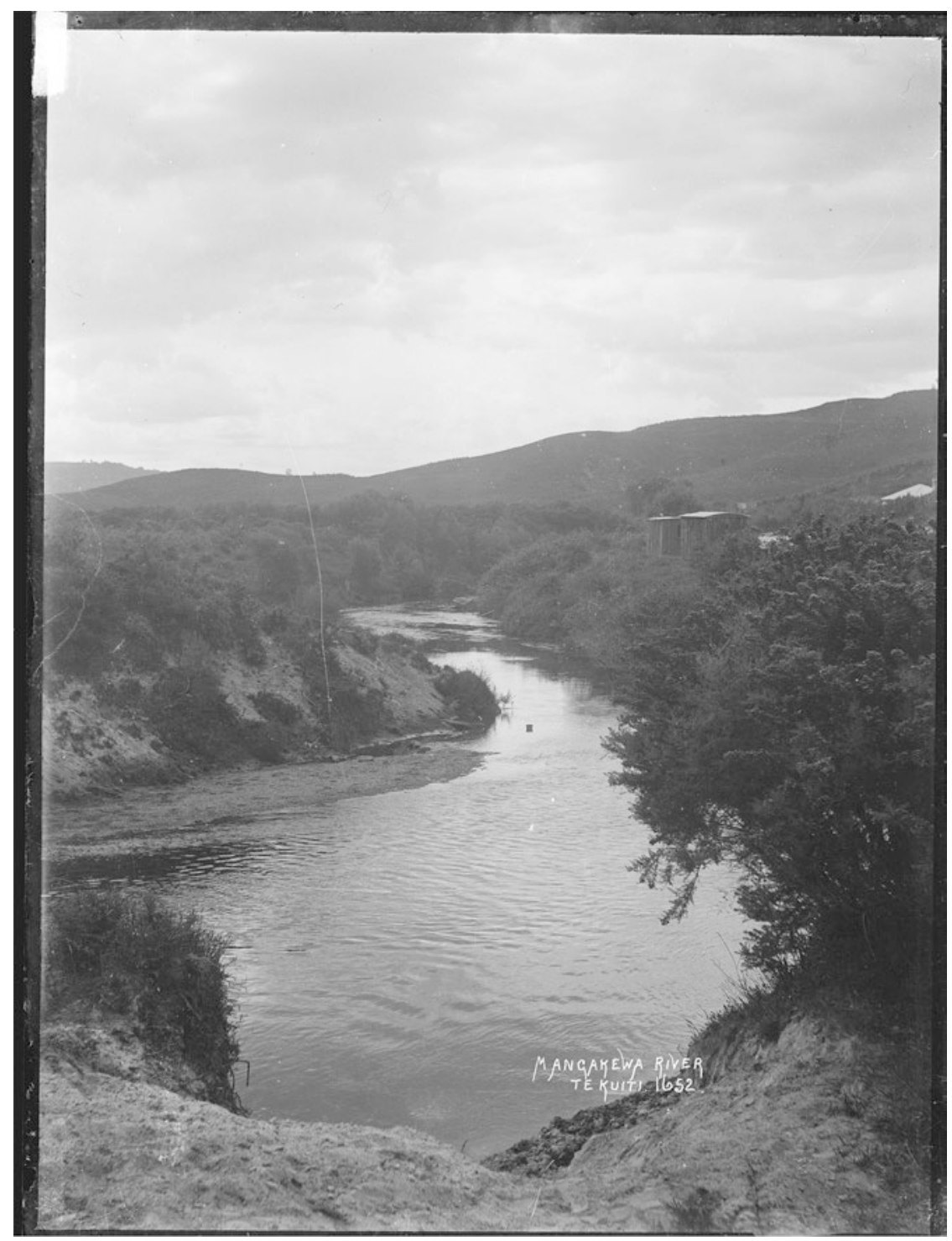

Fig. 5.1 View of the Mangaokewa Stream, near Te Kuiti. Photograph taken by William Archer Price, 1866-1948. Collection of post card negatives. Ref: 1/2-000698G. Alexander Turnbull Library, Wellington, New Zealand 


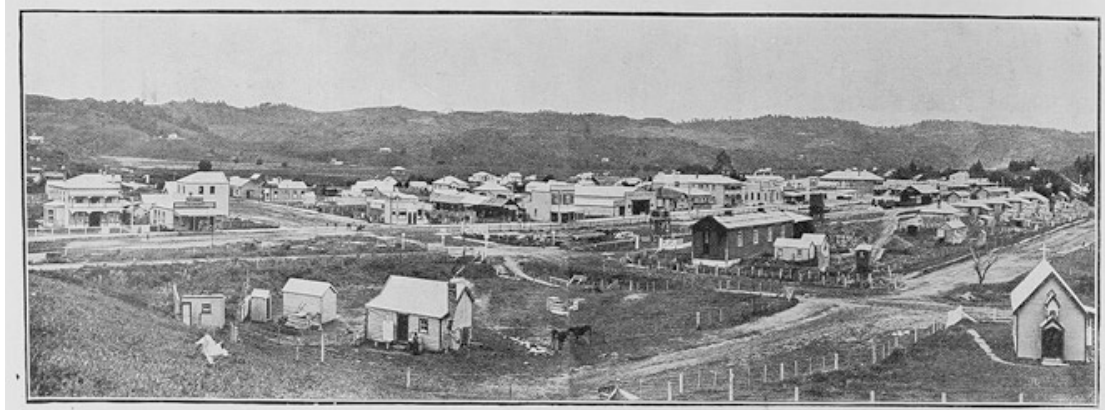

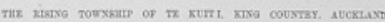

Fig. 5.2 Te Kuiti township 1909. (Source: AWNS 190912026 3, Auckland City Libraries, Auckland, New Zealand)

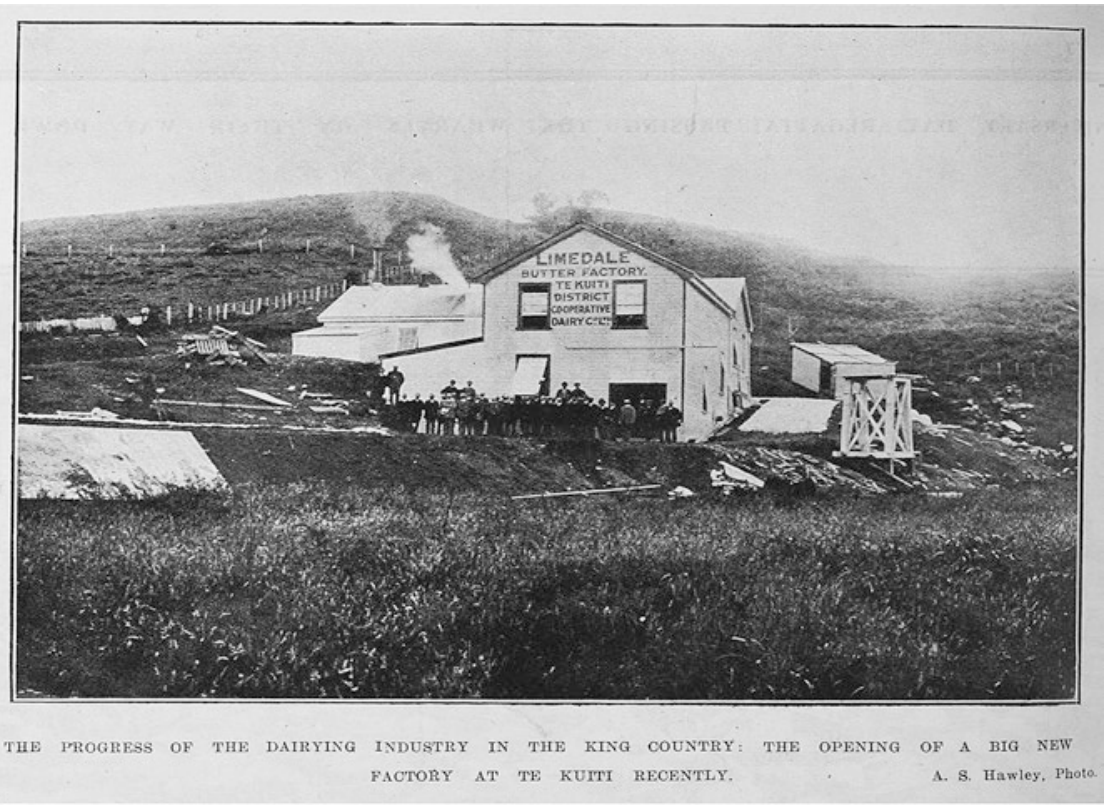

Fig. 5.3 Newly built factory near Te Kuiti (circa 1912). AWNS 1912020810 4, Auckland City Libraries, Auckland, New Zealand 
possible to "ascertain the degree of pollution" due to discharges from dairy farms (Fig. 5.3) (Pollution Advisory Council 1956, p. 48). The report did not acknowledge the significance of the waterways for Māori (as sources of water, food, medicinal, and art supplies as well as a treasure and an ancestor), though the authors noted that many Māori swam in the river.

\section{Consequences of Pollution on Health}

Despite being largely erased in official narratives about the river, Māori throughout the Waipā catchment continued to use and live beside the river; harvesting its freshwater biota such as tuna (freshwater eels), pūhā (stow thistles Asteraceae), and piharau (lamprey Geotria australis) for kai (food) for themselves, their whānau (family, extended family), their extended kin groups, and visitors. Sporadic mention in government reports and newspaper articles (typically accompanied by disparaging remarks about Māori 'uncivilised' ways of life) highlight that Pākehā (New Zealand European) were fully aware Māori continued to harvest resources from the Waipā freshwater system. These accounts also show Pākehā viewed Māori harvesting activities as being of lesser value than Pākehā-led economic development activities (extracting gravel from the riverbed, watering livestock, and discharging wastewater and dumping garbage into and beside rivers) and recreational activities (sailing and duck hunting in the peat lakes, rowing, boating, and sport fishing for trout) (Dixon 1937; Finlay 1923). Accordingly, the negative consequences of water pollution and other activities on Māori harvesting was of no concern to government officials (Department of Public Works 1928; Unknown Author 1900, 1935; Sullivan 1998). ${ }^{1}$

\footnotetext{
${ }^{1}$ It should be noted that from 1907 Pākehā (also referred to as New Zealand European) comprised the ethnic majority in the majority of the Rohe Pōtae (which encompassed the middle and upper Waipā River) and lower Waipā (within the wider Waikato region). In 1926 Māori were a minority in every part of Rohe Pōtae (except the small community of Kāwhia located on the West Coast of the district); and by 1936 Māori were the minority there as well (Robinson 2011). In many areas, particularly the towns of Otorohanga and Te Kuiti, they had become an even smaller minority. The New Zealand Census in 2013 reported that 71.6 per cent of the district's population identified as
} 
During the first half of the twentieth century, as untreated sewage consistently flowed into the waterways of the Waipā and Māori continued to collect water and aquatic food supplies, government health officials noted that Māori were experiencing higher incidence of infectious diseases as well as higher infant and adult mortality rates than Pākehā. Of particular concern was outbreaks of typhoid fever (a bacterial infection linked to exposure to water and food contaminated with faecal products) (Unknown Author 1936). However, health officials did not necessarily ascribe typhoid to the discharge of untreated human waste in the waterways (despite international medical knowledge demonstrating contaminated water and food were the cause of typhoid outbreaks). Instead, officials blamed Māori refusal to abandon communalism (such as tangi or funeral practices), poor hygiene practices, and continued use of (supposedly) unhealthy wetlands as reasons for Māori becoming unwell (and sometimes dying) from typhoid (Anonymous 1884; Gott 1916; Unknown Author 1897, 1916, 1926, 1937). In reality, a significant portion of Māori households in Te Rohe Potāe, in the early-to-mid twentieth century, relied on the waterways for their drinking and cleaning waters (as they were not connected to town water supplies) and also harvested a significant portion of their foodstuffs from the rivers and wetlands. Accordingly, Māori were more likely to be exposed to any bacteria in the waterways than Pākehā (see Figs. 5.4 and 5.5) (Unknown Author 1916) (Wood 1950). Despite this, the government took no specific actions to reduce the health risks that polluted water supplies posed to Māori during the first three decades of the twentieth century. Eventually, in 1936, the Chief Medical Officer of the Waikato and Rohe Potāe districts (Turbott) sought and gained approval from the central government for the provision and installation of water tanks for Māori in the district as a way of improving Māori health (Unknown Author 1936). However, the Native Minister warned that the government support was conditional and would only be provided on the basis that "care should be taken to see that Maori [were] not relieved of the responsibility for providing for [themselves] those essential amenities that [were] well within [their]

Pākehā, 36.4 per cent as Māori (compared to the national average of 14.9), 2.9 per cent as Pacific peoples, and 2.3 per cent as Asian peoples (Taonga 2020). 


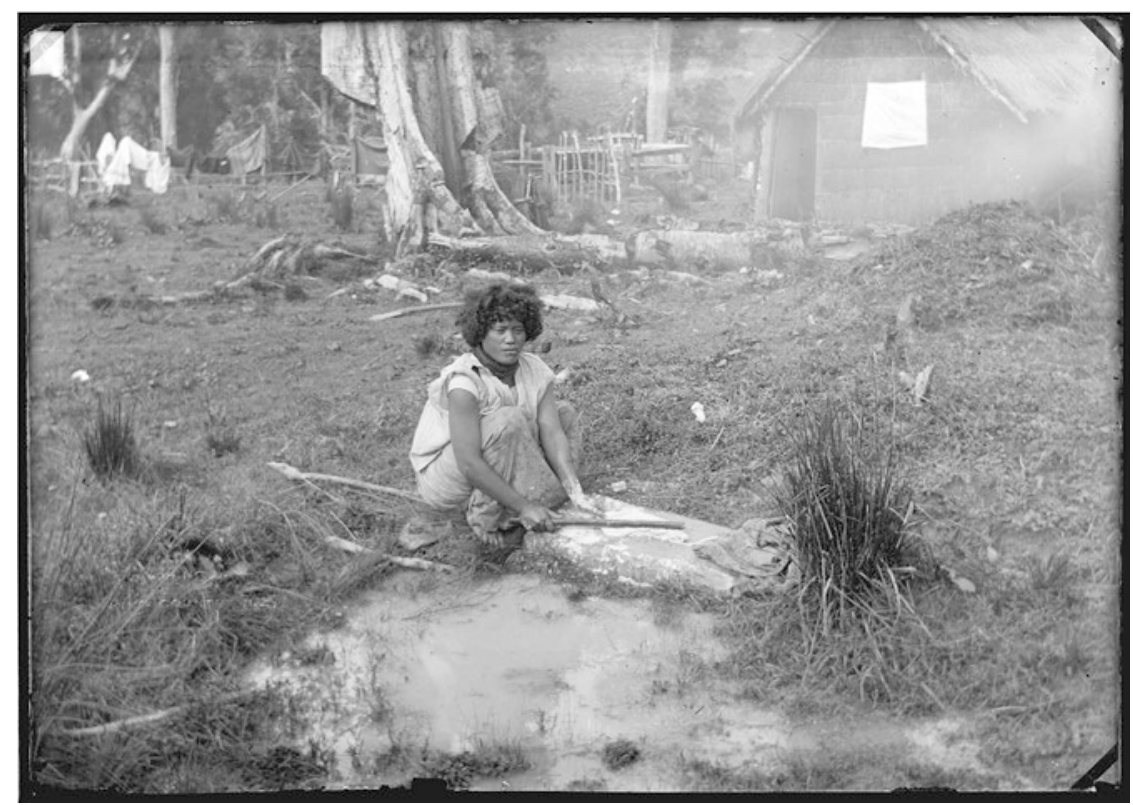

Fig. 5.4 Unidentified Maori woman washing clothes on a rock, Te Kauri, Otorohanga. (Source: Ref/1/2-140360-G. Alexander Turnbull Library, Wellington, New Zealand)

capacity to provide". The Native Minister warned that there was a "danger that a benefit conferred on the people today might be considered their right tomorrow", one should not give "something for nothing" (Cunningham 2014, p. 214). Whereas, the state deemed that Pākehā residents were automatically entitled to portable water supplies, for Māori it was deemed a privilege (rather than a right) that they needed to prove themselves worthy of.

Early definitions of environmental racism, emerging from the early US EJ movement led by Black civil rights leaders, framed it as intentional, overt, and malicious acts of environmental injustice on "communities of colour" (Figueroa 2001; Pulido 2016). From this definition, Māori's higher exposure to polluted waters (than non-Māori) in the Waipā cannot be read as intentional or malicious acts. Although, the failure to provide Māori with potable water supplies does indicate a lack 


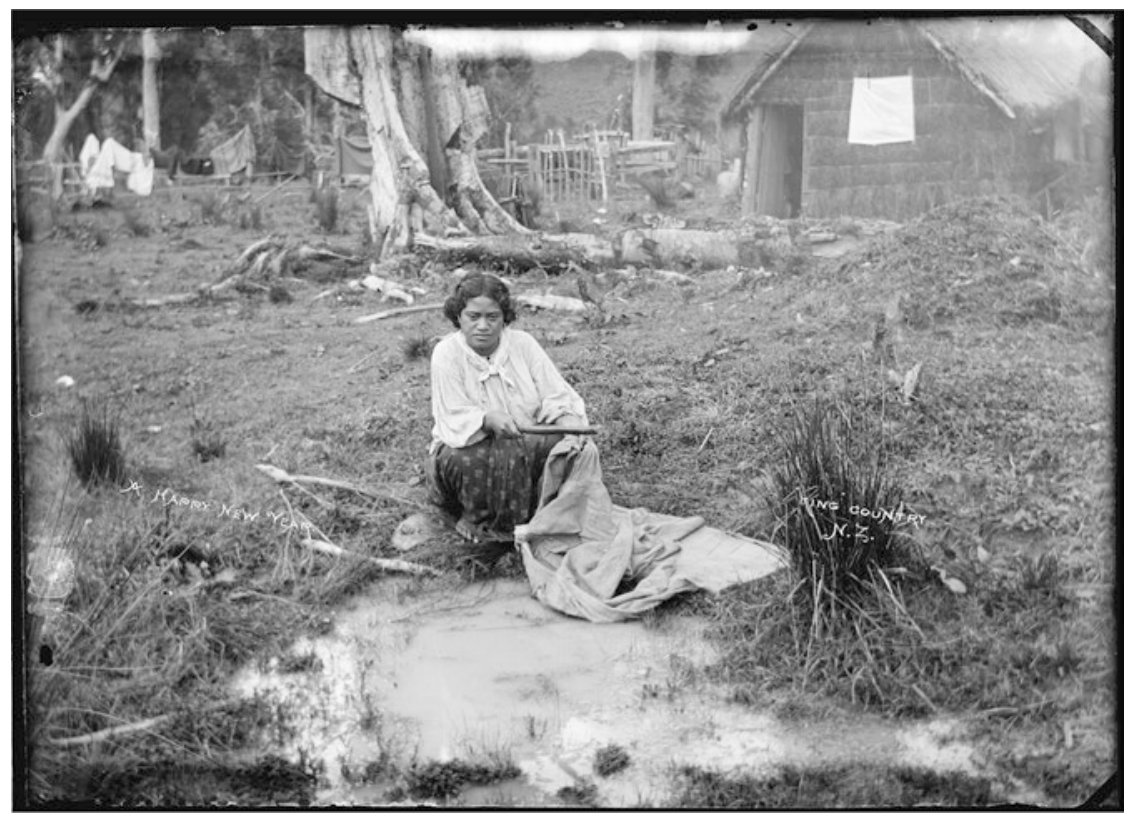

Fig. 5.5 Unidentified Maori woman washing clothes by a small pool, Te Kauri, Otorohanga District. Ref/1/2-140364-G. Alexander Turnbull Library, Wellington, New Zealand

of care towards Māori by the state, which breached the third article of Te Tiriti o Waitangi, which promised Māori the same privileges and protections given to all British subjects, and treated Māori as second-class citizens.

More recently EJ scholarship, however, extends understandings of environmental racism beyond the narrow definition of malicious intent by government, industries, individual actors (Pulido 2017a, b; Pulido and Peńa 1998). Instead, human geographer Laura Pulido and others, argue that environmental racism can be seen as a critical component of racial capitalism (discussed earlier in Chap. 4). Pulido work, in particular, documents how the US settler-colonial state consistently failed to address the environmental racism gap (between Black, Latinx and Indigenous peoples and the White US population) throughout the late twentieth and early twenty-first centuries, despite widespread awareness of it (recognised in federal and state policies), because of the financial and political 
costs. Meaningful actions to address these environmental injustices would not only be disruptive to industries, and the broader political system, and the settler-colonial state itself (Pulido 2017b). Instead, the US government (such as those run by the Environmental Protection Authority) developed a diversity of programs and policies in which it went through the motions (performances of regulatory activities), especially the participation of groups (Pulido et al. 2016), yet no meaningful changes occurred (Pulido 1998, 2017c). The issue was, therefore, not a lack of skill or knowledge about the nature of the problem, but rather a lack of political resolve that can be ascribed to racial capitalism (Pulido 2017b). Environmental racism, Pulido (2017b) argues, must be viewed in the context of a history of various arrangements of state-sanctioned violence which enables racial capitalism. Parallels can be seen in the Waipā context, despite the vast historical, socio-cultural, and political differences between Aotearoa and the US, in that Māori were expected to bear multiple burdens associated with state-led interventions. In addition to areas of land that were confiscated by the state (including the lower portion of the Waipā River catchment), Māori in the middle and upper catchment were expected to sell their lands at discounted prices to the government (as discussed in Chap. 4) for state-facilitated development efforts (including settlements and infrastructure) but received minimal benefits from such development projects (including limited access to freshwater supplies). Indeed, Māori (as individuals and members of whānau, hapūsub-tribes, and iwi) suffered poverty, poor health, and inequitable access to basic social services as a consequence of state actions, yet the state consistently justified such actions on the basis that they were cost effective and necessary to ensure the development of a productive economy and prosperous (Pākehā) communities. Indeed, the state's actions (and inactions) that allowed for the ongoing contamination of the Waipa waterways with waste products (effluent from people, livestock, and industries) were essential components of the "ecology of capitalism" in Aotearoa (Moore 2015). Water pollution and its negative impacts of Māori were not simply incidental by-products of human habitation and development, but rather interwoven into the fabric of the racial capitalistic settler-state. 


\section{Disposal of Waste}

According to Euro-Western understandings of waste management, industries and settlements required "sinks" to which they could remove and deposit polluted materials. These sinks were typically spaces (land, water, and air) accorded limited value. Just as specific places were devalued so too were bodies (human and more-than-human beings) which could function as "sinks" (Pulido 2015, 2017b). The Waipā River, its various tributaries, and its more-than-human entities were all sinks that sewage was discharge into alongside agricultural and industrial waste. Neither central nor local government authorities sought to implement the main recommendations of the 1956 report into the pollution of the Waikato River and the Waipā River (New Zealand Government 1956a, b; New Zealand Parliament 1953). The regional government authority (Waikato Valley Authority) argued that it was not responsible for water pollution (only flood risk), and instead devolved water pollution monitoring and regulation to local councils (Borough and County) (Unknown Author 1957). Accordingly, each borough and county council operated separate urban water infrastructure schemes with no consideration to what was happening upstream or downstream. For instance, the Otorohanga County Council extracted water for consumptive purposes from the Waipā River upstream of the township of Otorohanga, piped water to residents and businesses, and discharged the used water (including untreated sewage) back into the Waipā River downstream of the township. The same thing happened upstream at Te Kuiti and further downstream at Te Awamutu, and so on along the whole of the Waipā and Waikato rivers. Each council, therefore, was only concerned about water quality in so far as it pertained to the direct security of their township's water supplies; so long as there was no obvious health risk to local residents from town water supplies, then councils were unconcerned with ongoing pollution of the waterways.

Untreated human waste, therefore, continued to be pumped into the waterways with little consideration of consequences on people or biota. In the late 1960s Otorohanga Borough Council was still using the same septic tank system that was criticised in the 1956 report as was Te Kuiti 
Borough Council; (later the institutions were renamed in the 1980s the Otorohanga District Council ODC and Waitomo District Council WDC) (Unknown Author 1966a, 1967, 1968). In 1970, the Inspector of Health noted that the Waipā River "holds no immediate potential for human consumption, untreated, or stock watering" due to human effluent (Unknown Author 1970).

In 1974, ODC filed yet another application with the Waikato Valley Authority to permit it to continue to discharge untreated wastewater until the oxidation ponds were completed (Unknown Author 1974a). The application was, however, opposed by the Environmental Defence Society (formed in 1971 by a group of concerned lawyers and students) who submitted that the "discharge of effluent would detrimentally affect the receiving waters" and would negatively impact the recreational use, "scenic and natural features and fisheries" of the river, which were contrary to Section 20 (6) of the Water and Soil Conservation Act (1967) (Unknown Author 1974a, b, c, d, 1975a). The submission's referenced after recreational use, fisheries, and natural features; no mention was made to Māori connections and usage of the river and its resources. Despite the Environmental Defence Society's submission, the Authority granted Otorohanga County Council the right to discharge wastewater, which was extended to allow (for up to 600,000 litres of wastewater per day) once its new oxidation ponds were finished in mid-1975 for a period of ten years (Unknown Author 1975b).

No specific recognition (by the state or environmental groups) was given to how water pollution was (or could) negatively impact Māori lives, livelihoods, and their unique relationships with their whenua (land), awa (river), and moana (sea). Indeed, government legislation and assessments of the pollution status of the Waipā River (and other rivers in the country) were produced in the continuing haze of settler privilege. Western scientific knowledge, and the values, concerns and priorities of Pākehā entirely dominated discussions of water management, and mātauranga Māori (Māori knowledge), ways of seeing the world, and management approaches were wholeheartedly excluded from scientific, political and public discussions about water management until the closely decade of the twentieth century. The views of Ngāti Maniapoto and other iwi about water pollution were rendered largely silent in the written 
records of government officials in the first seven decades of the twentieth century; it seems that Pākehā officials did not deem Māori complaints about water pollution as worthy of writing down in their departmental memos. However, other sources (oral histories, memoirs, legal cases, and protests) highlight how Māori around Aotearoa continued to hold fundamentally different understandings of what constituted clean water and sought to challenge the settler state (and of Pākehā more generally) once even a voice within planning forums.

In addition to the settler-colonial violence and discriminatory policies, the reality of being an ethnic minority in their rohe (aka to Australian Aboriginal country and First Nations homelands) meant that Māori were more and more excluded (deliberately or incidentally) from decisionmaking processes about freshwater management. Thus, distributive inequities (higher exposure to environmental risks) were compounded by procedural injustices (institutional arrangements that prevented or restricted Māori participation in environmental planning processes), which were further exuberated by the failure to recognise Māori (values, knowledge and authority). In terms of Māori understandings of the Treaty, Māori are Treaty partners with decision-making authority meant to be shared between iwi and Crown; in terms of tikanga Māori (customary laws), iwi authority rests in their status as tangata whenua (who possess decision-making authority over an extended area of tribal lands/ waters that they shared with other iwi) and as mana whenua (who hold spiritual authority over a narrow area of tribal lands/waters that they do not share with other iwi). Misrecognition (of specific connections between iwi and their whenua and awa) then, for Māori, often overlapped with procedural injustices, wherein government policies and processes regarding river management (as were seen earlier in regard to wetland drainage) did not provide any space for Māori to be able to meaningfully participate in and be able to shape decisions. 


\section{The Resource Management Act and the Limits of Recognition}

By the 1980s, there were growing concerns about the effectiveness of environmental administration within Aotearoa in light of ongoing environmental degradation. For Māori, these concerns also extended to the limited opportunity for Māori to participate formally in environmental decision-making and management (Burton and Cocklin 1996). In the 1990s, more than 150 years after the signing of Te Tiriti o Waitangi, changes to legislation (most notably, the Resource Management Act 1991 (RMA)) and to local government sought to improve environmental management and decision-making (Harmsworth et al. 2016; Jacobson et al. 2016; New Zealand Parliament 1991; Thompson-Fawcett et al. 2017; Tipa et al. 2016). The passing of the RMA, by the Fourth Labour Government (who also were the only government to announce Treaty principles), ushered in fundamental changes to environmental management in Aotearoa by replacing 59 statutes and amending more than 150 others (Knight 2016, 2019).

The purpose of the RMA is "to promote the sustainable management of natural and physical resources" (section 5) (Fig. 5.6). To achieve this, the act mandates an effects-based approach to sustainable management and provides an integrated regime for managing land, water, air and ecosystems. By shifting the focus from the causes of degradation (as was the case with previous legislation such as the Water and Soil Conservation Act 1967) to the effects of activities on the environment, the RMA provided a regulatory regime (supposedly) capable of addressing the degradation and pollution affecting freshwater systems (Crow et al. 2018; Knight 2016; New Zealand Parliament 1967). It also allowed for greater public participation than previous legislation (Burton and Cocklin 1996; Lowry and Simon-Kumar 2017). For more than a century, Maori groups had demanded central government allow them to participate formally in environmental management; the RMA, for the first time, provided formal mechanisms for Māori to participate in planning processes (Burton and Cocklin 1996). 


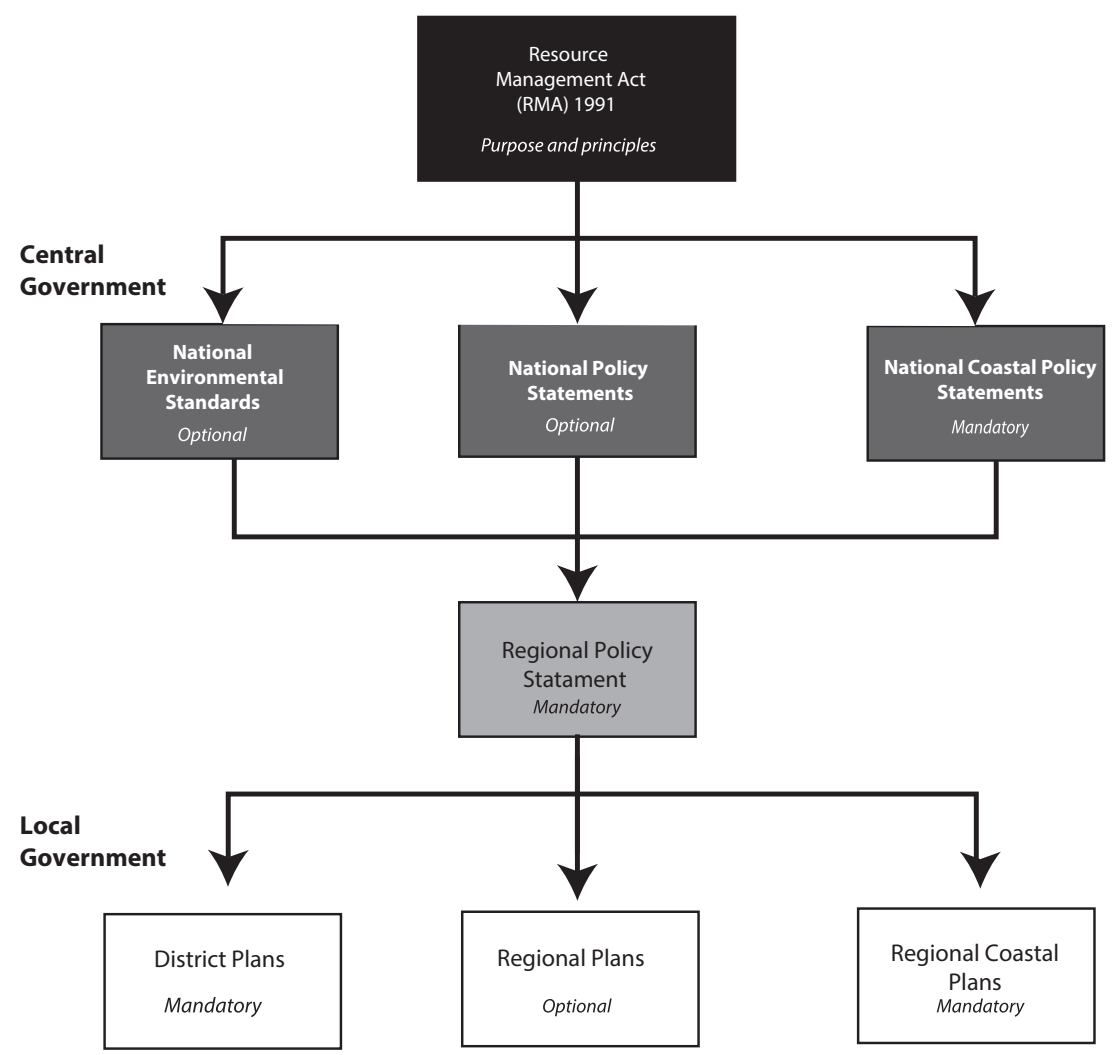

Fig. 5.6 Diagram outlining relationship between Resource Management Act and other local government mechanisms. (Source: Authors' Own)

The RMA includes specific provisions related to Māori in achieving the purpose of the act whereby all persons exercising functions and powers under it: shall recognise and provide for the relationship of Maori and their culture and traditions with their ancestral lands, water, sites, wāhi tapu (sacred sites), and other taonga (treasures, treasured possessions) (section 6e); shall have particular regard to kaitiakitanga (section 7a); and shall take into account the principles of the Treaty (section 8). Language of this kind was glaringly absent from earlier environmental (and other) legislation throughout the twentieth century (Burton and Cocklin 1996). Despite some limitations, the RMA did go some way to addressing 
problems of procedural inclusion characterising earlier environmental legislation especially by requiring consultation with Māori over plan changes, resource consent applications and, more recently, through iwi participation arrangements referred to as Mana Whakahono a Rohe (s58L) (Burton and Cocklin 1996; Lowry and Simon-Kumar 2017). However, the RMA did not necessarily address many of the causes of environmental injustices concerning water pollution in the Waipā River.

In 1989, the newly created Waikato Regional Council (WRC) assumed the responsibilities formerly held by the various catchment authorities, including the Waikato Valley Authority. From this time, and presumably because of pressure from WRC, Otorohanga District Council (ODC) was required to undertake monthly assessments of water quality and flow from its wastewater treatment plant (Unknown Author 1990); tests later highlighted the poor water quality in the stream and the negative impacts of aquatic biodiversity.

In 1995, WRC advised the ODC that it needed to apply for a resource consent (under RMA) for the operations of the wastewater treatment plant and its discharges (Unknown Author 1993, 1995a, b, c). In November 1995, the ODC contracted a private consulting firm (Works Consultancy Ltd) to assess the performance of its wastewater treatment system and prepare its resource consent application. The introduction of the RMA meant that all local government bodies, including the ODC, were required to "demonstrate active consultation with any party that may have an interest in the effects of your operation on the environment" (Unknown Author 1993, 1995a, b, c). The ODC decided to delegate its responsibilities for actively consulting with Māori and stakeholders to the consultants (led by engineer Peter Askey). The consultants formed an "Oxidation Ponds Working Party", made up of various representatives from different groups: community groups (Otorohanga Community Board, the Ratepayers Association); the farming industry (Federated Farmers); recreational advocacy bodies (Fish and Game); central government agencies (the Department of Conservation); environmental nongovernment organisations (the Royal Forest and Bird Society); and local Māori (Askey 1995a; Unknown Author 1995d).

The consultants' consultation process with iwi began with an initial meeting held at Te Kawa Marae on 11 October 1995 with Te Nehenehenui 
Regional Management Committee (Nehenehenu RMC). At the meeting, attendees from local iwi and hapū (affiliated to Ngāti Maniapoto) spoke at length about their views about the treatment plant and how waste was being inappropriately managed by the council. They reported how unpleasant smells were emitted from the plant and the treat wastewater it released into the stream was of poor quality (still filled with solid materials). By far and away the most significant issue, iwi attendees informed the consultant (Askey), was the practice of discharging human waste directly in the waterways. Human waste (irrespective of how it was treated using scientific methods and technologies) should not be disposed of into waterways. The iwi did not challenge the council on the grounds of science or engineering approaches (such as the treatment plant's use of oxidation ponds and filters) but instead argued that the discharge of waste into waster was wrong (on cultural, spiritual, and ethical grounds). One iwi representative, Bronwen Hughes, argued that the oxidation ponds and discharge into the waterways were "culturally insensitive" to tikanga because "they expose human waste" to everything in the river and breached rules regarding tapu (Unknown Author 1995e; Works Consulting Ltd 1995).

Iwi attendees spoke of how the discharges of wastewater were damaging fish life within the Waipā River catchment. The practices were decreasing the health and wellbeing of both humans and biota. Any "humans who might consume the fish or plants harvested from the waterways downstream of the discharge" from the Otorohanga plant were risking their physical and spiritual wellbeing (Unknown Author 1995e; Works Consulting Ltd 1995). The polluted waters meant Māori capacities to harvest foods from their mahinga kai (food gathering sites) were diminished, and they reported feelings of loss; in particular, members of local hapū were meant to harvest and cook foods sourced from their mahinga kai (such as tuna) to guests when they visited their marae and not being able to was a source of deep sadness and could diminish the mana (social status, power) of the hapū.

The 1995 Otorohanga working party, formed in haste by the Works Consultancy Ltd but representing the ODC, conducted its first meeting with tangata whenua at Te Kawa Marae. Two people from the Nehenehenui RMC (Richard Rangitaawa and Victor Tapara) were asked to join the 
working party as representatives of tangata whenua (Unknown Author 1995e). Nehenehenui RMC represented a number of hapū affiliated to Ngāti Maniapoto, who (as detailed in Chap. 2) trace their whakapapa (genealogical connections) to the Waipā River and consider the awa to be their kin. The consultants, whether by design or by ignorance of Māori protocols, did not invite other hapū or iwi (who possessed connections to the Waipā River) to join the working group. Later in December 1995, one representative from Te Mauri o Maniapoto was invited to join the working party (presumably because of complaints that the working party was excluding some tangata whenua groups). After inspecting the Otorohanga treatment plant one of the iwi representatives on the working group expressed serious concerns about the water quality in Mangaorongo Stream (a tributary of the Waipā). The impacts of wastewater discharged by the plant into the stream was negatively impacting both the quality of the water and health of aquatic fauna (fish species and tuna) health. And in doing so "food sources such as fish and eels for human consumption" were being contaminated, eating food contaminated by human waste threatened the health and wellbeing of tangata whenua, posing material risks (in terms of infectious diseases) and cosmological risks (in terms of breaching tapu and damage to mauri and wairua) (Unknown Author 1995f).

The consultants informed iwi representatives of the working group that they were right to be concerned about the health of their awa, as the discharged wastewater was causing adverse effects on the fish life in the Mangaorongo Stream. However, the consultants' reported that the majority of water pollution within the catchment was a product of run-off from farms (non-point of sources pollution) and therefore the discharge of wastewater was only a small contributor (Askey 1995b).

As a consequence of their investigations and consultations, the consultants recommended to the ODC various remedial engineering solutions to address the issues at the ODC treatment plant, including increased sludge removal, pond aeration, and the construction of a wetland. Iwi preferences for treated waste to be discharged first into onto the land were briefly noted ("earth contact for final treatment prior to mixing with water in the stream"), however no specific engineering solutions were discussed as the idea was deemed too financially costs (Unknown Author 
1966b). The ODC and WRC, on receiving the report in July 1996, was supportive of the consultants' recommendations; however, iwi were less euthasiastic (Environment Waikato 1996).

The consultants distributed their draft report and recommendations to iwi as part of consultation processes. Nehenehenui RMC, although supportive of the general aims of the proposed engineering works to improve water quality, raised questions about how the council was going to mitigate the odorous gases, monitor the discharges, address the impacts of discharges on the health of biota and people, and taken into account Māori values. Nehenehenui RMC once again raised the question of why it was necessary to discharge human effluent into the waterways and why an alternative approach could not be adopted. There were "many other cultural considerations" that were being missed by consultations, and it was "culturally ... quite offensive" for Māori to drink water that was (even in part) contained human waste products (Unknown Author 1996a). Other iwi representatives, from Te Mauri o Maniapoto, meet with the consultants in Otorohanga in September 1996 and reiterated the concerns of Nehenehenui RMC discharge of treated wastewater into the stream.

The consultants rejected Māori requests for land-based waste disposal due to financial considerations (it would require large areas of land and would cost the council a lot of money) (Askey 1996). However, they did eventually propose the replacement the final 10 to 20 metres of the effluent line with an earth trench (before the waste flowed in the stream) and to establish a wetland to go some way to address Māori preferences for land-based disposal. Te Mauri o Maniapoto representatives were pleased with the proposed measure as it would "allow for the treated effluent to contact with [Papatūānuku_Earth Mother] before entering the stream, and the treated effluent would look like a natural spring flowing into the earth" (Unknown Author 1996b). And despite their ongoing concerns about water quality, ultimately, both Te Mauri o Maniapoto and Nehenehenui RMC agreed (in March 1997) to support the resource consent application of the ODC. Their support was conditional on the basis that: the proposed engineering works included the construction of both an earth trench and wetlands; the resource consent duration was reduced 
(from 15 years to 10 years); and ongoing water quality monitoring were conducted.

Even after both groups agreed to support the ODC, many iwi members expressed continuing opposition. Three individuals from the Nehenehenui RMC (Massey Ormsby, Rachael Ormsby, and Jacqui Amohanga) filed an additional submission to the WRC in November 1997 that outlined their continuing concerns about human waste entering their awa.

The submission declared the discharge of wastewater "into the Mangaorongo Stream must cease completely!" and called for the council to embark on a long-term shift in wastewater management focused on land-based disposal to address the environmental degradation of their awa (Amohanga et al. 1997, p. 9).

Ngāti Maniapoto opposition to the disposal of waste products remained fundamentally interwoven with Māori understandings of waste as tapu and the need to ensure that tapu was kept apart (which we outlined in Chap. 3). With the risks posed by breaching tapu by discharge human waste into waters extending beyond simply scientific assessments of water quality, but this did not mean that Māori only drew on mātauranga to justify their concerns but rather multiple knowledges were used to try to communicate to non-Māori audiences (predominately Pākehā) and get them (be it government officials, consultants, scientists, and other decision-makers) to take their perspectives seriously. However, Māori understandings (of water, waste, health, and wellbeing) were frequently lost (or misrecognised) by non-Māori (who were primarily Pākehā) in discussions over not only the operations of the Otorohanga treatment plant but waste management schemes that were taking place throughout the Waikato region and the entire country.

Throughout the 1990s, Māori individuals and groups filed petitions, staged protests, submitted claims to the Waitangi Tribunal, and mounted legal cases that challenged government environmental management approaches. The Waitangi Tribunal was established as a permanent commission of inquiry to investigate Māori claims that the Crown was not honouring the terms of the Treaty of Waitangi. Tribunal responsibilities include researching and holding public inquiries into historic and contemporary claims filed by any Māori individual or group regarding 
Crown breaches of the Treaty, reporting back to claimants and the Crown about inquiry findings, and making recommendations to the Crown regarding how it can address Treaty breaches (reconciliation and restorative justice) (Jones 2016; Mutu 2018, 2019; Wheen and Hayward 2012).

Many Māori complaints drew attention to how freshwater and saltwater spaces were continually being polluted by human waste, and how the discharge into water was a fundamental breach of rules around tapu. Māori vocally campaigned for their values to be respected and that direct actions be taken to stop the discharge of waste products into waterways. Waste products, once discharged into waterways, result in both the receiving waters as well as all those beings that are connected to those waters (through whakapapa) become unhealthy; their mauri (life force) and wairua (spiritual integrity) diminished by the tapu of human waste. Accordingly, from a tikanga perspective, human waste products (even if treated using the best scientific and technological methods) should always be kept away from bodies of water (be it a river, harbor, or sea). As Māori scholar, an expert on tikanga (customary laws), Sidney (Hirini) Moko Mead (from iwi Ngāti Awa) articulates:

The rules of tapu advise Maori to separate the clothes one wears from cloths associated with food such as table clothes and tea-towels. Babies' napkins and cloths associated with menstruation are kept away from food utensils. By extension these rules apply to the separation of sewage which include some human body parts .... This very tapu mixtures needs to be separated from the food we eat not only because of its spiritual attributes but also for health reasons. The institution of tapu operates for the well being of people ... Break the rules and immediately people are unsettled in the minds, are fearful of their well being because [their] basic beliefs are being transgressed. Blood is tapu ... A body part of a living person is tapu. Excreta is tapu ... There is no problem [in terms of Māori customary laws] with the return of excreta or body parts to Papatūānuku [the Earth Mother] ... What is abhorrent is the idea of associating biosolids with the food chain. (Mead 2016)

Mead's quote is in line with those articulated by Māori scholars and leaders. For instance, Aila Taylor, a key spokesperson for Te Atiawa 
during the Waitangi Tribunal's inquiry into the Crown's failure to honour its Treaty obligations, expressed similar views about waste disposal:

What comes from the earth goes back to the earth. We believe that human waste should go back to the earth. We believe that anything to do with human waste should have nothing to do with food ... seafood should not be gathered from reefs polluted by an [sewage disposal] outfall. This belief is not just related to 'scientifically detectable' pollution; even if scientists 'proved' that an outfall was not polluting, we would be unhappy gathering seafoods from a reef near such an outfall. (Taylor and Te Taha Māori 1986, p. 2; Waitangi Tribunal 1993, pp. 12-14)

Both Taylor's and Mead's quotes (and those earlier from representatives of Ngāti Maniapoto) highlight Māori understandings of human waste continued to be found up in the principle of tapu. The ways in which the tapu of waste pollutes water and food (both of which carried their own tapu status) is not able to be quantifiable or measured by Western scientific knowledge but instead represents a fundamentally different way of knowing the world; such ontological and epistemological differences, as we and other scholars previously argued, should not be positioned in opposition, integrated together, or privileged one over the other, but instead allowed to exist as equally separate and important systems of knowing, thinking and doing) (Hopkins et al. 2019; Howitt and Suchet-Pearson 2006; Parsons et al. 2017) (see Fig. 5.7). Accordingly, throughout Aotearoa Māori individuals and groups (since the passage of the RMA allowed them processes to voice their concerns) articulated over and over again to decision-makers their opposition to waste being discharged into water.

Through an autoethnography study, for instance, Māori scholaractivist Angeline Greensill (iwi Waikato-Tainui, hapū Tainui) documents her own personal (and those of her whānau and hapū) involvement in efforts to prevent discharge of waste into Whaingaroa Harbour (now more known by its settler-name of Raglan). Located on the West Coast of the Waikato region, the township of Raglan's treatment plant parallels those in operation along the Waipā River. The local council constructed a new sewage system, which consisted of two oxidation ponds on top of 


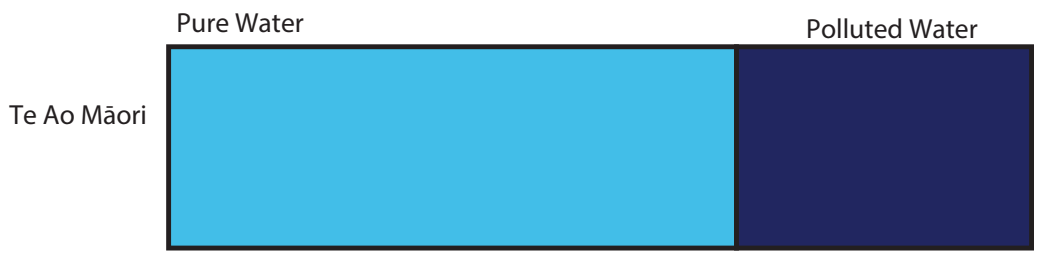

Clear defintion between different states of water (tapu/noa)

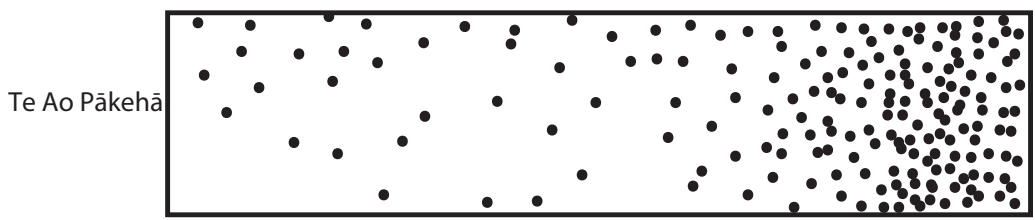

Water with a low level of impurities

Severely polluted water

Simplified of Māori and Pākehāconceptualisations of water pollution (Adapted from James and Pawson, 1995, p. 120)

Fig. 5.7 Māori and Pākehā representations of Water, adapted diagram from James \& Pawson (1995, p. 120)

an important wāhi tapu (Te Rua o Te Ata) and built the discharge pipe over land belonging to the local hapū (Tainui). Hapū members, including Greensill and her mother (the Māori activist and leader Evia Rickard), protested against the council's actions, but were unable to stop the new plant being built. The pipeline discharged treated wastewater (which included human waste) into the mouth of the harbour. Greensill reports that, as a consequence of the discharge of sewage and other acts of environmental violence committed against their waters, hapū no longer could swim in their waterways (due to health concerns). Likewise, hapū could no longer harvest culturally important foodstuffs as a consequence of the plethora of acts of ecological violence (including effluent discharge, agricultural run-off, sedimentation, removal of native plants and animals, 
unsustainable fishing practices) as the productivity of their mahinga kai noticeably declined. Greensill records how the loss of certain species of flora and fauna, including seahorses and stingray, from the habour is particular distressing for hapū as those animals (as ancestors and kin to tangata whenua) become "mere memoirs [and] more sad stories" to tell one's mokopuna (grandchildren) rather than more-than-human actors in the landscape/waterscape/seascape that one holds ongoing relationships with it (Greensill 2010, p. 33).

During the 1990s, Greensill and her mother filed an objection on behalf of Tainui hapū, paralleling the actions of Ngāti Maniapoto hapū, when the local council (Waikato District Council) filed new resource consent applications to discharge waste into their harbour. Negotiations between Tainui, WDC (Waikato District Council), and WRC, which cumulated into a series of Environmental Court cases that clearly highlighted the different knowledges that representatives from Tainui and government bodies relied on. The district council drew primarily on scientific technical witnesses and case law to justify why the regional council (the same one responsible for approving the ODC consent) should afford less weight to Māori concerns. The district council (through its lawyers) argued that: "Māori cultural and spiritual beliefs as to protection of water from discharges should not be accorded an absolute entitlement". Moreover, the economic development needs of the entire district and its population, lawyers for the district council argued, needed to take precedence over the minor concerns of tangata whenua. Similarly, the district council's engineer downplayed Māori concerns about the wastewater disposal as mere "perceptions", with the "cultural issue" of waste disposal something that could not be provided through scientific assessments and therefore held no weighting (be it in terms of water management practices nor legal standards).

In 2004, the Environment Court ruled in favour of the Waikato District Council and against the Tainui hapu to permit the council to continue to discharge waste into the harbour. The court announced that there was scientific evidence that showed that the disposal of treated effluent would only cause a small amount of negative effects on the environment and most environmental degradation was caused by farming and deforestation practices (Greensill 2010, p. 61). The Environment 
Court's decision stated that the evidence presented by Tainui was "merely assertions" (cultural and spiritual rather than scientific) "not so much of effects as such but of indirect or consequential results of the discharge". The judge, therefore, placed far greater weighting on the words of nonMāori 'experts' (who were overwhelming Pākehā men with engineering and planning degrees) and New Zealand (settler-colonial) case law rather than Māori 'experts' (rangatira/chiefs, kaumatua/elders) and tikanga Māori.

The decision of the judge in 2004 was unsurprisingly given the state's legal system's foundations in British colonial laws as well as the continued dominance of settler values that privileged scientific (Pākehā) knowledge and technological interventions over other ways of knowing. It reveals strong parallels to what was happening in the Waipā River. The Tainui and Otorohanga examples are just two of countless others from across Aotearoa where Māori continue to experience injustices in environmental planning regimes (despite sections of the RMA being designed to include Māori in decision-making processes and recognise Māori values). Māori values were (and still are) often dismissed and denigrated as merely (trivial, uncivilised) cultural or spiritual perspectives, which hold less weight than the ideas, values, and practices of the dominant settler society (originating from Western Enlightenment thought) (Greensill 2010, p. 33). Thus, while the RMA did signal a significant change in legislation that allowed for some degree of Māori participation in decision-making (procedural inclusion) and recognition of Māori as a culturally distinct group with specific interests in their local environment, it did not translate into any substantive changes to environmental management. Indeed, how the RMA was interpreted and applied by local government bodies across the country (including within the Waipā River Catchment) did not necessarily resolve many of the environmental injustices experienced by iwi (as settler-colonialism and capitalism remained hegemonic).

The recognition of Māori interests in water and their concerns about water pollution failed to challenge the status quo and did not necessitate that the state (be it local government or central government) reform in any significant way. We trace this failure (tied to the persistent recognitional injustices as well as lack of participatory parity) partly to the structure and operations of local governments. There is an ever expanding 
literature on the relationships between Māori and local government (Bargh 2016; Hayward 2011; Ryks et al. 2010), including those focused on partnerships (Lewis et al. 2009) and environmental co-management arrangements, highlights the problematics of recognition based politics in Aotearoa (Coombes and Hil 2005; Forster 2016; Lowry and SimonKumar 2017; Morgan and Te Aho 2013; Muru-Lanning 2012; Te Aho 2015). Avril Bell, for instance, highlights two significant interconnected problems in the structural underpinnings of iwi-local government relations: (1) the issue of the political representation of Māori (or the lack therefore) in elected local government bodies; (2) local government not being given the status of Treaty partners (Bell 2018). At the national level, there are seven Māori seats (out of a total of 120 members of parliament), with Māori voters given the choice every five years if they enrol on the general electoral roll or the Māori roll (with the number of Māori seats adjusted to reflect how many people are on the Māori roll as a proportion of total population). Local government bodies, since the Local Electoral Amendment Act (2002), have had the choice of creating dedicated Māori seats on local councils; however, only one has done so. The Bay of Plenty Regional Council established three Māori seats alongside four general seats, thus ensuring that there was fair representation for the 28 per cent of the Bay of Plenty population who were Māori. Māori individuals can stand for local body elections and some do so. However, Māori are "chronically underrepresented" in local councils as only 3.6 per cent of local councillors in 2007 were Māori (even though Māori made up 15 per cent of the population) (Hayward 2011, p. 187). Moreover, local councillors, who were elected to general seats, were not required to represent Māori but rather the entire community. Thus, "Māori issues and interests [were] even more seriously underrepresented within the local government sector than even these figures suggest" (Bell 2018, p. 82). In addition, while the central government by 2002 did recognise iwi (even if it was and still is inadequate), they did not place the same obligations on local government (as they were not classified as Treaty Partners). From the perspective of local government, Bell (2018) argues, hapu and iwi were simply accessible and convenient organisations to consult with to meet their duties (under the RMA and Local Government Act) vis-à-vis consulting with and involving Māori in decision-making 
processes. Thus, while most local authorities did possess some form of consultation processes (as demonstrated in the ODC wastewater treatment plant example) in place with iwi and hapū, these processes fell short of the Treaty governance partnerships that iwi sought.

Unsurprisingly (given the lack of Māori representation), local governments continued to place greater weighting on the submissions of nonMāori groups, even when groups employed non-scientific arguments to justify their concerns. For instance, the only submission the WRC received (aside from Māori submissions) that expressed opposition to the ODC's resource consent application about the Otorohanga treatment plant, in 1996-1997, came from the local chapter of Fish \& Game. The not-for-profit organisation, Fish \& Game (originally formed as acclimatisation societies that established to introduce exotic plants and animals to Aotearoa), sought to ensure that additional conditions were added to the resource consent to protect sport fish (trout) and game birds (ducks). Fish \& Game requested that the ODC planted riparian vegetation downstream of the discharge point (which was incorporated into the resource consent conditions) (Auckland and Waikato Fish and Game 1997). It is worth noting that while Fish \& Game's request for riparian planting was simply incorporated into the council's policy for the treatment plan, the numerous requests made by Māori (lodged in the days, months, years, and decades before and after Fish \& Game's submission) to protect and/ or restore vegetation along the riverbanks were rejected on the basis that vegetation impeded the flow of water and created flood hazards.

\section{Procedural and Recognition Environmental (In) Justices: Continuity and Change}

In the first decade of the twenty-first century, Ngāti Maniapoto Trust Board (as the representative body of the wider Ngāti Maniapoto iwi) articulated their concerns about the declining water quality of the Waipā River. Two iwi reports, the State of the Environment Report (Kowhai Consulting Ltd and Ministry for the Environment 2002) and the Ngāti Maniapoto Management Plan (Kowhai Consulting Ltd 2007), highlight 
changes within the Waipā river and the negative implications on their mahinga kai. The 2002 state of environment report summarises:

Looking at the Waipa River today, it is hard to believe that our tupuna spoke of a time not so long ago when the waters of the Waipa were clear, deep and blue. Within the clear, clean waters of the Waipa were fat eels, large crayfish, and a variety of fish, a plentiful source of food. Children in the vicinity of the Waipa made regular trips to the river for swimming, eeling and fishing. For most of us today, this is a dim memory or a legend of times past. The waters of the Waipa now run muddy brown, polluted with farm run-off, industry discharges, sewerage spills and stormwater drainage. Many food species have disappeared from the river, and the remaining tuna/eels within the river may not be safe for eating. (Kowhai Consulting Ltd and Ministry for the Environment 2002, p. 7)

Ngāti Maniapoto highlights how the degradation of the Waipā River and its tributaries is an indicator of the state of not only the hauora (health) and mauri of the river, but also the interconnections of awa, whenua, biota, and people (specifically mana whenua):

The streams and rivers are the lifeblood of our environment, and they tell us about the state of our environment, the forests, lakes, oceans and seashore. As with the human body, if the blood of the environment is poisoned, the rest of the body will also suffer. (Kowhai Consulting Ltd and Ministry for the Environment 2002, p. 11)

"While not ... opposed to development", Ngāti Maniapoto stress, that the historic costs of development "to the environment is unacceptable. It is time to-restore some balance" (Kowhai Consulting Ltd and Ministry for the Environment 2002, p. 11). The above quotes indicate, once again, how Māori ways of thinking (in this instance those of Ngāti Maniapoto) are place-based and kin-centric and premised on the reciprocal relationships between human and more-than-human actors, which differed markedly from Western ways of thinking (particularly those held by decision-makers who were and still are the ones making decisions about how water and waste are managed in Aotearoa). 
The Otorohanga District council, following on from the 1996 consultants' recommendations and its successful resource consent application, did acknowledge (to some degree) hapū and iwi concerns about river health and Māori opposition to water-based waste disposal methods. As a requirement of its resource consent to continue to discharge wastewater into the stream, which was granted by the WRC, the district council constructed an earth trench (consisting of a channel with rocks placed it and a wetland) to address Ngāti Maniapoto concerns (Unknown Author 1966b, 1995f, 2010a). The ODC was also meant to investigate landbased disposal options as per Māori requests (but it did not undertake these investigations before 2010). Indeed, the works that ODC did undertake, to respond to Māori concerns (about declining water quality, loss of biodiversity, noxious smells, and breaches of tapu), were all haphazard and made with minimal investment (in terms of time and money). The earth trench and wetlands appear to be constructed as an afterthought or a tokenistic act to appease Mãori; simply a box ticking exercise that the district council went through to ensure it could get its resource consent to continue to operate its waste management plant with minimal changes to the status quo. The council instead spent the vast majority of its resources (financial and human) on upgrading the oxidation plant and limited resources on the fundamental problem (in terms of tikanga Māori) of the disposal of waste into waterways. Unsurprisingly, a few years later (in 2010) when a new consultancy firm (this time Cliff Boyt Consulting) was employed by ODC to prepare yet another resource consent application, the consultants found both the earth trench and wetlands were substandard (Stammers 2008; Unknown Author 2008, 2009a). Neither were functioning as intended and water quality remained low. The earth trench was, the new engineering consultant reported, unsalvageable due to the large amount of organic matter blocking the flow of water (Boyt 2010). The wetlands (planted less than five years prior) were declared a financially imprudent approach to water quality improvement and an unusable expense. Wetlands, in his view, did not purify wastewater as fast, as cheaply, or as effectively as the use of other hard infrastructure (engineering-based) options. A far more sensible option (from a cost/benefit analysis) was for the ODC to invest in new "in-pond or after-pond treatments" and entirely de-commissioned the 
wetlands within two years (Boyt 2010). The consultant did not specifically address how these proposed waste management strategies (to abandon the earth trench in favour of a drop line, to decommission the wetlands, and to construct new oxidation ponds) would mitigate Māori concerns about tapu. The consultant, however, did note that the council still needed to conduct an investigation of land-based disposal strategies to appease local Māori (as promised until its previous resource consent) to demonstrate it could be simply merged into the consultancy firm's "assessment of the environmental effects" of wastewater (Boyt 2010; Unknown Author 2010a). Herein, Māori values were merged by the consultant to be one and the same as environmental values.

Despite the RMA specifically recognising and providing for the values and concerns of Māori to be taken into account in planning decisions, this legislative recognition did not translate into substantive changes to water (and waste) governance and management in the Waipā. The ODC, like other councils in the Waikato region, continued to discharge wastewater into the stream despite vocal and persistent opposition from Ngāti Maniapoto and other iwi. Māori academic Sydney Mead outlined, in 1998, the potential dangers associated with human waste for people in his submission to the Wellington Council about waste discharges into the region (cited by Pauling and Ataria 2010, p. 9): "excreta was tapu and for health reasons this waste product of the human body needed to be kept as far away as possible from where the villagers cooked their food, ate, talked and slept", and it effluent was always kept away from water (be it in a river, lake, or sea). Indeed, the settler-state (local and central government) and the court system remained largely ignorant of Māori perspectives about water pollution. Both the settler-colonial legal order (discussed further in Chap. 6) and the governing bodies who were responsible for monitoring and (supposedly) maintaining the 'quality' of freshwater defined pollution through Western scientific knowledge and did not provide for Indigenous ways of knowing (centred in the Waipā context on mātauranga and tikanga). As Coulthard aptly summarises: "one does not expend much effort to elicit the countless ways in which the liberal discourse of recognition has been limited and constrained by the state, the courts, corporate interests, and policy makers so as to help preserve the colonial status quo" (Coulthard 2007, p. 451). Indeed, he argues, that 
the "colonial powers ... only recognize the collective rights and identities of Indigenous peoples insofar as this recognition does not throw into question the background legal, political and economic framework of the colonial relationship itself" (Coulthard 2007, p. 451). Indeed, none of the consultative processes instituted as a consequence of the RMA nor the Local Government Act and the tokenistic actions taken to address Māori opposed to water-based modes of waste disposal challenged the political, legal, economic and social framework on which settlercolonialism rested (New Zealand Parliament 1991, 2002).

Although councils were obligated (as consent authorities) to recognise and provide for Māori values under the RMA, what this meant in practice was far from ideal (or just). Indeed, since acts of recognition (of Indigenous peoples as culturally distinct groups holding specific values and connections to particular lands/waters) remains largely vested in the apparatus of the settler nation, recognition remains only partial, inadequate, and amounted to misrecognition at times. The RMA provisions, however, as the ODR noted did not given Māori the right to veto developments but instead required the council to take into account the cultural preferences of Māori (clear evidence of where recognition-based justice fails to deliver EJ for Indigenous peoples as Coulthard asserts) (Coulthard 2014). In the case of the Otorohanga wastewater system, the WRC simply recommended that the ODC consider replacing the system when it was practicable. The ODC, as with other district councils in the Waikato Region, argued that were no land-based schemes that were not a viable option (due to financial expense) and also that the waste discharged into waterways already being of a very high standard.

Later reports by the ODC declared that land-based disposal approaches were not feasible for the Otorohanga district due to the high financial costs to the council and its ratepayers; the council noted it would need to purchase hectares of prime agricultural land for private landowners which would be exceedingly expensive. Instead, the council suggested that it could cut drainage channels across the re-established wetlands (constructed as a consequence of consultation in 1995) to allow the treated wastewater to be discharge into the stream; with the malfunctioning earth trench replaced by a drop pipe (Unknown Author 2011a). The consultant made no reference to how the new measures would specifically 
address Māori concerns about whenua-based waste disposal, their reports of continuing poor quality of water in the steam, and declines in biodiversity. Money rather than mauri was the main focus of council.

Just as the appropriation and control over land, labour arrangements, and social and economic policy are all significant components of sociopolitical and economic systems in settler-states, so too are the ways water resources are extracted, treated, and disposed of. A wealth of EJ scholarship conceptualises racism and the practices of waste disposal as externalities, rather than key parts of racial capitalism. However, since racism persistently produces differential value, it stands to reason, Pulido argues (Pulido 2017b, p. 529), that capital "would incorporate this uneven geography of value into its calculus". The ways in which government persistently chose to (mis)manage the waters of the Waipā River catchment (draining its wetlands, realigning and dredging its riverbeds, constructing flood levees, and discharging (un)treated sewage into its waters) highlight the low status afforded to both rivers and Māori bodies (and values) by the settler-state (embedded within racial capitalism). The decisions of councils and courts to oppose Māori proposals about how wastewater should be disposed of were consistently rejected on the basis that either their knowledge (mātauranga) was not scientific evidence (just spiritual or cultural beliefs) or (in situations where mātauranga and science were in agreement) the argument turned to the high financial costs of alternative approaches. Indeed, this is a familiar strategy within recognition-based approaches, noted by scholars including Bargh and Coulthard, whereby the state recognises Indigenous identities and articulates the importance of including Indigenous peoples' within frameworks (neoliberal, settler-state, co-governance) that are designed and sanctioned by the state and in doing so, other alternative social, economic, political, and ecological arrangements are excluded (Bell 2018; Coulthard 2014; McCormack 2018).

Elsewhere in the country, however, land-based disposal (such as Rotorua) of waste was positioned as a way to address Māori concerns about the disposal of human waste into waterways. Proposed alternatives to replace the trench included (once-again) disposal on the land, the construction of a larger rock-lined channel, or a special Papa-tū-ānuku channel (like that constructed in another waste treatment plant in Hastings). 
In the township of Hasting (East Coast of the North Island), for instance, a Papa-tū-ānuku channel was specifically designed to include aspects of Western scientific and mātauranga Māori practices and address iwi concerns. The Hasting District Council describes the treatment processes as comprising:

fine ... screening, screening washing and compaction; grit removal ... wastewater pumping ... Biological Trickling Filters ... a Papatuanuku (rock) passage to restore the mauri of the treated human waste (kuparu) before discharge ... [as well as a] bark bed biofilter [that] captured air ... to remove odour. (Boyt 2010)

Both iwi and council reported that they were satisfied with the channel. The Hasting example highlights that, despite substantive ontological and epistemological differences, common ground can be found between Te Ao Māori (the Māori world) and Te Ao Pākehā (the New Zealand European world) when it comes to water management. Yet, it requires an approach (procedural inclusion, recognition, and distributive equity) that embraces both legal and ontological pluralism, and extends beyond the confines of Western science and socio-cultural values. However, no in-depth investigations were conducted into land-based disposal options in Otorohanga (or in the neighbouring district of Te Kuiti, which also discharged into a stream that feeds into the Waipā River), and councils remained wedded to long-standing approaches.

In the years 2008 and 2009, three emergency discharges of sewage into Mangaorongo Stream occurred when the oxidation ponds become full and threatened to overflow due to high rainfall events. These and other incidences prompted the WRC to issue a formal warning letter to the ODC about its failure to comply with its resource consent condition. The WRC frequently sent warning letters to district councils (including ODC and even more frequently to Waitomo District Council that operated the Te Kuiti wastewater treatment plant) because of compliance issues (see Tables 5.1 and 5.2); including failures to: conduct required water testing; submit monitoring reports to WRC and iwi; consult with iwi; construct upgrades to treatment plant; and maintain or improve water quality in streams. Throughout 2011 and 2012, for instance, the 
ODC received only warnings from the WRC about its failure to comply with its resource consent for the wastewater treatment plant; most notably, the continuing discharges of high volumes of wastewater that contained faecal coliform counts in excess of the allowed standards as well as

Table 5.1 Waikato Regional Council's assessment of the Otorohanga wastewater treatment level of compliance (as per its permit to discharge waste into environment) between the years 1981 and 2012

\begin{tabular}{|c|c|c|}
\hline Date & Status given to plant & Enforcement action \\
\hline 1981 & $\begin{array}{l}\text { Wastewater treatment plant } \\
\text { deemed to be well operated } \\
\text { and maintained }\end{array}$ & $\begin{array}{l}\text { No enforcement action } \\
\text { recommended }\end{array}$ \\
\hline $\begin{array}{l}\text { November } \\
1984\end{array}$ & $\begin{array}{l}\text { Plant well maintained and } \\
\text { operated }\end{array}$ & $\begin{array}{l}\text { No enforcement action } \\
\text { recommended }\end{array}$ \\
\hline July 1989 & $\begin{array}{l}\text { Wastewater discharge from } \\
\text { oxidation ponds considered } \\
\text { satisfactory }\end{array}$ & $\begin{array}{l}\text { No enforcement action } \\
\text { recommended }\end{array}$ \\
\hline $\begin{array}{l}\text { February } \\
1993\end{array}$ & $\begin{array}{l}\text { Minor compliance issues } \\
\text { reported }\end{array}$ & $\begin{array}{l}\text { No enforcement action } \\
\text { recommended }\end{array}$ \\
\hline March 2002 & $\begin{array}{l}\text { Significant non-compliance } \\
\text { reported }\end{array}$ & $\begin{array}{l}\text { No enforcement action } \\
\text { recommended }\end{array}$ \\
\hline $\begin{array}{l}\text { December } \\
2002\end{array}$ & High level of compliance & $\begin{array}{l}\text { No enforcement action } \\
\text { recommended }\end{array}$ \\
\hline April 2004 & Partial compliance & $\begin{array}{l}\text { No enforcement action } \\
\text { recommended }\end{array}$ \\
\hline June 2004 & High level of compliance & $\begin{array}{l}\text { No enforcement action } \\
\text { recommended }\end{array}$ \\
\hline June 2005 & High level of compliance & $\begin{array}{l}\text { No enforcement action } \\
\text { recommended }\end{array}$ \\
\hline June 2006 & High level of compliance & $\begin{array}{l}\text { No enforcement action } \\
\text { recommended }\end{array}$ \\
\hline August 2007 & High level of compliance & $\begin{array}{l}\text { No enforcement action } \\
\text { recommended }\end{array}$ \\
\hline $\begin{array}{l}\text { October } \\
2008\end{array}$ & $\begin{array}{l}\text { Significant level of } \\
\text { non-compliance }\end{array}$ & $\begin{array}{l}\text { First formal warning letter } \\
\text { issued by Waikato Regional } \\
\text { Council }\end{array}$ \\
\hline $\begin{array}{l}\text { November } \\
2009\end{array}$ & Significant non-compliance & $\begin{array}{l}\text { Second formal warning letter } \\
\text { issued }\end{array}$ \\
\hline $\begin{array}{l}\text { September } \\
2010\end{array}$ & Significant non-compliance & Third formal warning issued \\
\hline August 2011 & Significant non-compliance & Fourth formal warning issued \\
\hline August 2012 & Significant non-compliance & $\begin{array}{l}\text { No enforcement action } \\
\text { recommended }\end{array}$ \\
\hline
\end{tabular}


Table 5.2 Waikato Regional Council's assessment of the Te Kuiti wastewater treatment plant level of compliance (as per its permit to discharge waste into environment) between the years 1989 and 2012

\begin{tabular}{|c|c|c|}
\hline Date & $\begin{array}{l}\text { Status awarded to } \\
\text { treatment plant }\end{array}$ & Enforcement action \\
\hline June 1989 & $\begin{array}{l}\text { Plant met its consent } \\
\text { conditions, although the } \\
\text { facilities were old and } \\
\text { needed replacing }\end{array}$ & No enforcement action taken \\
\hline $\begin{array}{r}\text { March } \\
1993\end{array}$ & $\begin{array}{l}\text { Plant well maintained and } \\
\text { operated, however there } \\
\text { was no facilities or } \\
\text { technologies to measure } \\
\text { the daily flow of water } \\
\text { or bacterial counts }\end{array}$ & No enforcement action taken \\
\hline $\begin{array}{l}\text { February } \\
2000\end{array}$ & $\begin{array}{l}\text { Plant awarded a non- } \\
\text { compliant status }\end{array}$ & $\begin{array}{l}\text { Matter referred to Waikato Regional } \\
\text { Council's Regulatory Committee. } \\
\text { Action plan developed and an } \\
\text { abatement notice issued in October } \\
2000 \text { (due to failures of the } \\
\text { Waitomo District Council to meet all } \\
\text { the conditions of the action plan) }\end{array}$ \\
\hline May 2001 & $\begin{array}{l}\text { Significant level of } \\
\text { non-compliance }\end{array}$ & No enforcement action recommended \\
\hline June 2003 & $\begin{array}{l}\text { Significant level of } \\
\text { non-compliance }\end{array}$ & No enforcement action recommended \\
\hline June 2004 & $\begin{array}{l}\text { Significant level of } \\
\text { non-compliance }\end{array}$ & No enforcement action recommended \\
\hline June 2005 & $\begin{array}{l}\text { Significant level of } \\
\text { non-compliance }\end{array}$ & No enforcement action recommended \\
\hline May 2006 & $\begin{array}{l}\text { Significant level of } \\
\text { non-compliance }\end{array}$ & No enforcement action recommended \\
\hline $\begin{array}{l}\text { September } \\
2007\end{array}$ & $\begin{array}{l}\text { Significant level of } \\
\text { non-compliance }\end{array}$ & First formal warning letter issued \\
\hline $\begin{array}{l}\text { November } \\
2008\end{array}$ & $\begin{array}{l}\text { Significant level of } \\
\text { non-compliance }\end{array}$ & Second formal warning letter \\
\hline July 2010 & $\begin{array}{l}\text { Significant } \\
\text { non-compliance }\end{array}$ & $\begin{array}{l}\text { Third formal warning letter issued; } \\
\text { referred to Waikato Regional } \\
\text { Council's Enforcement Decision } \\
\text { Group who issued an abatement } \\
\text { notice (pending the completion of } \\
\text { wastewater treatment plant } \\
\text { upgrades) }\end{array}$ \\
\hline
\end{tabular}


Table 5.2 (continued)

\begin{tabular}{lll}
\hline Date & $\begin{array}{c}\text { Status awarded to } \\
\text { treatment plant }\end{array}$ & Enforcement action \\
\hline July 2011 & $\begin{array}{c}\text { Significant level of } \\
\text { non-compliance } \\
\text { July 2012 } \\
\text { nonificant level of } \\
\text { non-compliance }\end{array}$ & No enforcement action recommended \\
\hline
\end{tabular}

the discharge of water directly into the stream (bypassing the wetlands) (Unknown Author 2012a, b). However, the WRC chose not to adopt any strong mechanisms of enforcement (such as issuing fines as it was empowered to do under the RMA) and still continued to resort to letter writing (Unknown Author 2009b, c, 2010b, c). Yet, words did not translate into actions and the water continued to be polluted (Unknown Author 1998, 1999a, b).

In July 2011, the ODC undertook another round of consultation with iwi, as part of its efforts to secure another set of resource consent application for the operations of the Otorohanga treatment plant (set to expire in 2012) (Unknown Author 2011b, c). The Nehenehenui RMC was appointed to conduct a 'cultural assessment' for the council and formed a working group; the group was made up of four members from Nehenehenui RMC, one representative from Maniapoto Māori Trust Board and one from Whariki Business Services. The working group conducted a site visit to the Otorohanga wastewater treatment plant in September 2011 and consulted with other tangata whenua in the area. The group reported that there was a general lack of maintenance evident throughout the entire treatment plant, including its oxidation pond, wetland, and surroundings. In addition, they observed that cattle were freely able to access the stream, and there was a complete lack of native vegetation along the banks of the stream. Ultimately, the group concluded that the current operations failed to address the long-term goal of Māori, which was "to restore the waterways ... to a level acceptable to the iwi and where there is an abundance of food which is safe to eat and water is suitable as drinking water" (Unknown Author 2011d).

Although the Nehenehenui RMC supported the ODC's application, they made a long list of recommendations to the council on how it should 
improve the water quality of its treated wastewater (Unknown Author 2011d). The first and second recommendations centred on Nehenehenui RMC being actively involved (encapsulating the Treaty principle of partnership) in drafting the management plan and monitoring the operations of the Otorohanga waste treatment plant. The ODC response was that it would provide a copy of the operations and management plan within six months of the ODC being issued with a new resource consent, and invite Nehenehenui RMC to undertake a site visit to the treatment plant once a year during which time they could discuss the previous year's monitoring results. Other recommendations focused on the operations of the treatment plant including improvements to the maintenance of wetlands, drains, and oxidation pond. Nehenehenui RMC wanted suitable native vegetation planted along the drains (within the treatment plant) as well as along the stream (including at the outlet where the wastewater was discharged) as well as the area fenced off from cattle. Indeed, an earlier scientific assessment conducted by the National Institute of Water and Atmospheric Research (NIWA) in 2002 recommended that riparian planting take place along the banks of the Mangaorongo Stream (including the area where the wastewater was discharged into the stream). In response to Nehenehenui RMC requests, the ODC declared it was unwilling to plant the stream surrounds with vegetation as it was too financially expensive, difficult to achieve (being in public and private ownership and on steep banks), and ineffective (which would do make no difference to water quality and the number of aquatic fauna). Yet, earlier, when Fish \& Game requested similar action be taken, the council agreed to plantings (to provide habitat for trout fishing and duck hunting) (Cunningham 2014; Unknown Author 2011d). Another Nehenehenui RMC recommendation was that the district council adopt a report card approach to the management and monitoring of the waste treatment plant to ensure iwi were kept fully informed about the performance of the plant as well as the health of their awa. Once again, the ODC likewise sought to sidestep this recommendation and suggested instead that the council provide a copy of its annual monitoring report (which it was required to submit to the WRC) to the Nehenehenui RMC.

The issue of water pollution was further exacerbated by district councils' reluctance to provide accurate information about water quality and 
treatment plant operations to local iwi and hapū. Access to information is a critical part of a groups' abilities to participate in decision-making about environmental issues, with procedural justice closely tied to people being able to access information about their environment, which includes any hazardous materials and practices that may impact communities. District councils frequently failed to: conduct the necessary tests of river/ stream water quality; submit its monitoring reports to the WRC and iwi/ hapū; investigate land-based waste disposal; and take into account tikanga Māori (that is to say Māori values and practices). All of which, in various ways, were legal requirements under the RMA and councils' resource consents. The conflict between what local governments were saying and what they were actually doing in practice, along with the general perceived secrecy of the local councils, rearticulated Ngāti Maniapoto's and other iwi's wider concerns about the settler nation's failure to honour Te Tiriti o Waitangi and its apparent inabilities to address freshwater degradation. If we return once again to EJ as procedure, there is clear evidence that the government (despite the introduction of new legislation aimed to address Māori lack of inclusion) did not provide open and inclusive processes of decision-making. Such processes involve enabling access to spaces and information that were previously restricted. In this way, the continued lack of procedural justice for Ngāti Maniapoto is intimately interwoven with the settler-colonial-state (and it's various agencies) "closed geography of information, access and power" (Walker 2009, p. 628). Procedural fairness, Walker and other EJ scholars observe, is built on fluidity of movement of ideas, perspectives, knowledges, and peoples across institutional boundaries as well as between different worlds (plural ontologies and epistemologies), allowing for "open rather than constrained networks and deliberation" (Walker 2009, p. 628). In the Waipā River case study, the RMA established processes that required governments to exchange information with members of the public (including iwi and hapū) but did not achieve procedural fairness because far too often information supplied was incomplete (with monitoring and reporting infrequent). The real-world geographies of flows (or lack) of information, iwi encounters within decision-makers, and power relations between groups are critical tests of procedural fairness, which highlight the continuation of injustices due to lack of participatory equity (between 
Pākehā and Māori, and iwi and the Crown). The open provision of information about water, biodiversity, and land and the deliberative possibilities of participation in consultation processes (which we later highlight in our discussion of the new co-governance arrangements over the Waipā River in Chap. 7 are in practice highly socially, culturally, politically and spatially differentiated, with iwi, hapū and whānau still finding it difficult to access information about their local environment. In addition, as we explore in Chaps. 7 and 8, ways in which people can access to adequate resources (money, time, and social support) also present barriers for iwi being present in participatory spaces; from attending a hui (meeting) on a marae to discuss a resource consent application, to being able to give a presentation to a regional council's hearing about the application, or even taking part in an international summit on Indigenous water justice, substantive resources and time-space constraints make it harder for iwi to participate in council mandated procedures. Yet, as Schlosberg's work previously demonstrates, the experiences of injustice is rarely singular (Schlosberg 2003, 2013). In the case of Ngāti Maniapoto's experiences of EJ stemming from water pollution, inequitable distribution (of environmental harms and goods), limited participation, and a lack of recognition of Ngāti Maniapoto values and knowledge (and broader tikanga Māori) all worked to produce injustice.

Over the twentieth century and into the first decade of the twenty-first century the Crown and its agencies, ${ }^{2}$ including local governments, consistently excluded or marginalised Māori knowledge and values (including those centred around the tapu of waste and water). In doing so, the settler state created a series of environmental injustices through misrecognition. Likewise, natural resource governance and management approaches (underpinned by settler-colonial laws, knowledge systems, and technologies) were created and operated in ways that did not allow for Mãori voices to be heard for much of the twentieth century; even

\footnotetext{
${ }^{2}$ From the perspective of Māori iwi the Crown includes local government, whereas from the perspective of the Crown (as outlined in the Local Government Act, 2001) local governments are not part of the Crown (which only includes central government and central government departments) and are not Treaty partners with Māori. Due to the current distinct under legislation, local governments do not possess the same legal requirements as central government agencies to act in partnership with Māori. See Bell (2018).
} 
when the RMA provided mechanisms for Māori to articulate their perspectives in planning regimes, government bodies often attempted to bypass their legal obligations. Thus, another layer (this time procedural) was added to the environmental injustices experienced by Māori. Lastly, the pollution that continues to run off into waterways means that Ngāti Maniapoto are unable to access the environmental goods (in the form of the native freshwater food sources_-such as tuna, inanga (whitebait), and kākahi (freshwater eel)__as well as swimmable and drinkable rivers) that they value the most. Since Māori ways of being (along the Waipā River and its tributaries), despite the plethora of changes wrought by colonisation and capitalism, continue to centre on the capacities of whānau/ hapū/iwi to access and use their awa and its resources, we argue that Māori experiences of water pollution in the Waipā were and are more severe than experienced by non-Māori. Indeed, whereas Pākehā values were taken into account by decision-makers and strategies adopted to protect those biodiversity resources that Pākehā prioritised (most notably trout and ducks), Māori values were not. Thus, another injustice (this time a distributive injustice) was deposited onto Māori.

In response, the ODC requested that the WRC place their resource consent application process on hold while it further consulted with mana whenua. On the 28 April 2012 the ODC gave representatives from mana whenua a tour of the Otorohonga wastewater treatment plant and explained the proposed upgrades to the plant. The council reported that mana whenua were comfortable with council's plans and Māori only continued to oppose the proposed resource consent condition that related to the amount of E coli. concentrations that was allowed to be permitted in the treated wastewater discharged into the stream. However, ODC refused to modify this condition as it would too financially expensive for the council to comply with the request of mana whenua (presumably because it would involve further investments in treatment processes). Moreover, local hapū whose rohe included the Mangaorongo Stream (through the Nehenehenui RMC cultural assessment report) already expressed their support for the ODC resource consent application (Boyt 2012; Unknown Author 2012c). Eventually, the WRC resource consent panel concluded that the ODC had gone to: "significant lengths to include the interests of tangata whenua in [its] application [for resource 
council] and ensure that their concerns [were] met". The WRC concluded that the negative impacts on "tangata will be less than minor". Accordingly, the WRC ruled in favour of the ODC and granted it resource source for a period of 25 years (Unknown Author 2012d, e). The Waipā River catchment is defined as a vulnerable river accordingly to the Ministry of Environment (see Fig. 5.8) due to its high level of degradation (which parallels those of many rivers in Aotearoa).

\section{Conclusion}

Regional councils were (and still are in 2020) responsible for issuing the resource consents in their territorial boundaries and ensuring that resource consent holders (in this instance the ODC and Waitomo District Council) complied with their resource consent provisions. WRC sought to ensure (to a limited degree) that the ODC acted in accordance to its resource consent for the Otorohanga wastewater treatment plant. However, the ODC continues to remain wielded to its past policy and waste management approaches, even when there were continuing problems with poor water quality and Māori dissatisfaction with water-based disposal. The situation was paralleled almost exactly at the Te Kuiti treatment plant except worse. The plant, operated by the Waitomo District Council, discharged even worse quality water into the Mangaokewa Stream (filled with high levels of bacteria and nutrients). Submissions by representatives of Ngāti Maniapoto about the Te Kuiti treatment plant drew attention to issues of: poor water quality; depiction of native aquatic fauna; iwi preferences for land-based disposal; and the district council's failure to maintain the plant to the required standards (Hauauru Ki Uta Regional Management Committee 2011; Jensen 2011). Despite the ongoing non-compliance status at the Te Kuiti treatment plant, the WRC did not hold Waitomo District Council to account for its breaches of its resource consents and merely issued warnings (Hauauru Ki Uta Regional Management Committee 2011). Even though WRC could possessed the greater regulatory powers (such as imposing fines on district councils) to ensure the RMA was followed, it took no such action to protect the Waipā awa from further degradation. The archival resources of we 


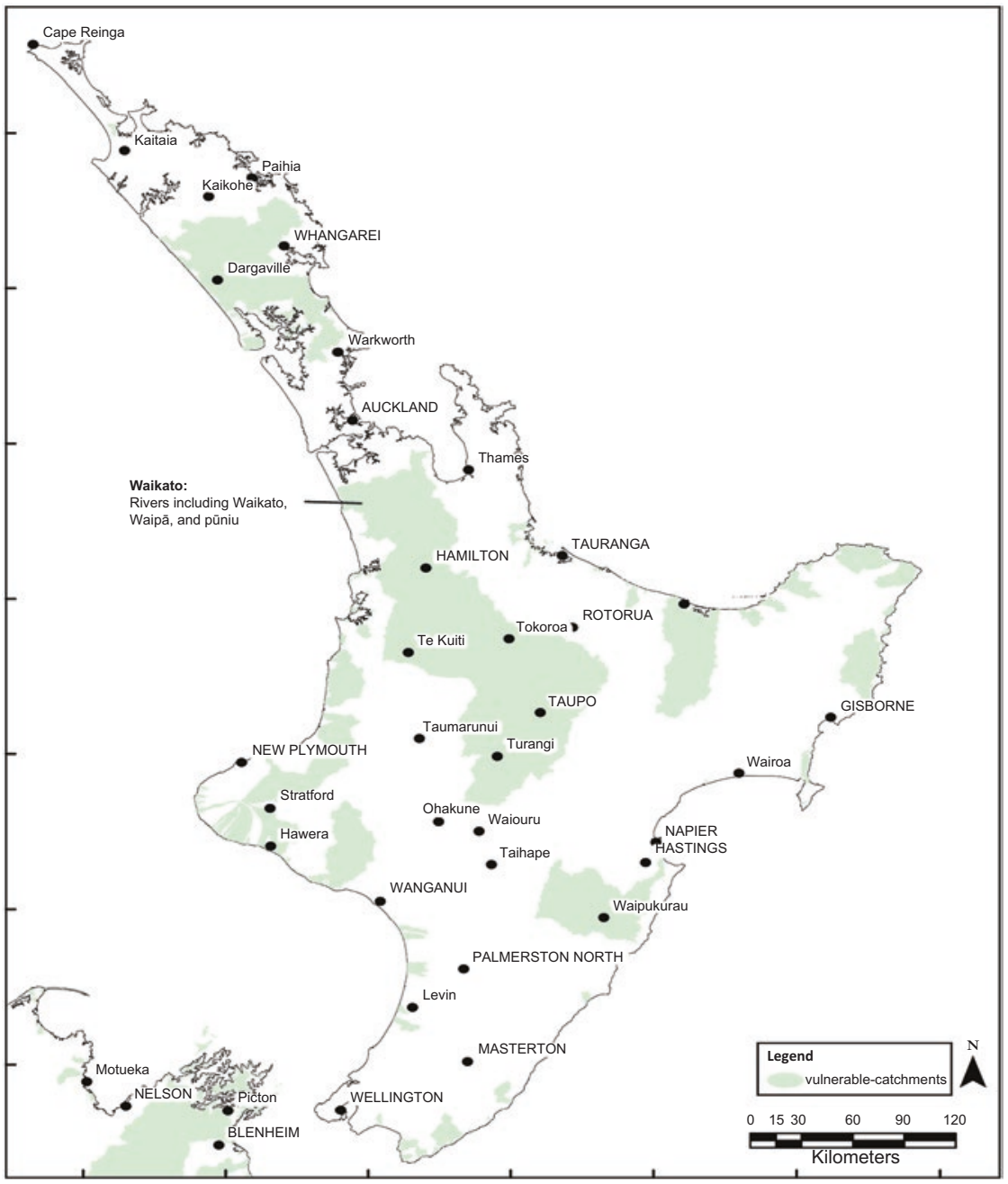

Fig. 5.8 Map showing locations of "vulnerable" river catchments in the North Island of Aotearoa New Zealand in 2017. Ministry of Environment defines vulnerable rivers as one that are significantly degraded. (Source: Authors own) 
analysed ends in 2012, however, as of 2020, the water quality along the length of the Waipā River and its tributaries remains exceedingly poor. From its headwaters to when it joins with the Waikato River, the Waipā River ranks in the bottom 25 per cent of rivers in Aotearoa New Zealand in terms of water quality.

In the next chapter, we move into the post-Treaty settlement era in Aotearoa wherein certain iwi (including Ngāti Maniapoto and WaikatoTainui) are forming co-governance and co-management arrangements (sharing authority between iwi Māori, Crown and local governments) about the management of rivers, forests, and other geo-entities. Such arrangements represent new hybridised governance structures that hold the potential to remake and address environmental injustices. However, the problems of local government-iwi relationships continue to come to the fore (as we outline further in Chaps. 9 and 10). In this chapter we highlight how Māori interests in and concerns about water pollution were consistently disregarded and downplayed by the settler-state. The attempts at procedural inclusion and recognition (under the RMA) consistently faltered (both at a local government level and within the Environment Court) because the rules of the game were set by those in power and thus reinforced the status quo. Council officials (elected and employed), consultants (engineers and scientists), and judges decided what knowledge was worthy of inclusion and what strategies should be approved. Despite consultation processes with iwi, wherein Māori tried to articulate their worldviews, tikanga, and mātauranga about their awa and their aspirations for improved water quality to largely non-Māori decision-makers, councils continued to privilege western scientific knowledge over mātauranga and Te Ao Pākehā over Te Ao Māori. The language of finance was used to back up council decision-making, Māori preferences for land-based disposal (be it on pastures or into wetlands) were declared too financially costly, too time consuming, and less ineffective that existing engineering approaches. Here we turn our focus back to the limits of both procedural and recognition theories of EJ and asked (paraphrasing Bargh 2018): How can relationships be restored (between iwi and the state, between people and the river, between humans and morethan-humans) when one side of the relationship, such as the settler-state, is defining the process and taking virtually no responsibility for changing 
their existing values, attitudes, and beliefs, let alone their behaviours? The act of recognition, we argue, needs to extend beyond the settler state recognising Māori iwi (tribes) as a culturally distinct groups who are significantly and/or uniquely impacted by an environmental issue (in this instance water pollution). It needs to be situated from 'below' rather than 'above': with Indigenous peoples themselves defining the terms of recognition and strategies. Central to this will be a broad scale recognition of Māori ontologies and epistemologies (including tikanga) about humanwater relations, and the interconnectivity and dependency of all beings (human and more-than-human) which we discuss more in our next chapter.

\section{References}

AJHR. (1900). H-21 Rivers Commission: Interim Report of Commission to Inquire into Certain Matters Relating to Watercourses. In Appendices of the Journal of the House of Representatives. Wellington: New Zealand Parliament. Retrieved 20 May 2019, from http://paperspast.natlib.govt.nz/parliamentary/AJHR1900-I.2.3.2.48.

AJHR. (1910). C-14 Waihou and Ohinemuri Rivers (Report of Commission Appointed to Inquire into Silting of); Together with Minutes of Evidence and Exhibits. Appendices of the Journal of the House of Representatives. Wellington: New Zealand Parliament. Retrieved 20 May 2019, from http:// paperspast.natlib.govt.nz/parliamentary/AJHR1906-II.2.3.3.2.

AJHR. (1925). C-11a Rangitaiki Land Drainage (Report of the Commission Appointed to Inquire into and Report Upon). Wellington: Government Printer. Retrieved 16 July 2017, from http://www.atojs.natlib.govt.nz/cgi-bin/ atojs? $\mathrm{a}=\mathrm{d} \& \mathrm{~d}=\mathrm{AJHR} 1925-\mathrm{I} \cdot 2 \cdot 2 \cdot 2.15 \& \mathrm{e}=\% 2 \mathrm{D} \% 2 \mathrm{D} \% 2 \mathrm{D} \% 2 \mathrm{D} \% 2 \mathrm{D} \% 2 \mathrm{D}$ 10\%2D\%2D1\%2D\%2D\%2D\%2D\%2D\%2D0--.

Amohanga, J., Ormsby, R., \& Ormsby, M. (1997, November 24). Further Response on Behalf of Nehenehenui Regional Management Committee Submission by Jacqui Amohanga, Rachael Ormsby, and Massey Ormsby. 60 41 51A, Volume 2, Waikato Regional Council, Hamilton. Unpublished. Anonymous. (1884, February 14). Typhoid Fever Amongs the Maoris a T Hokianqa. New Zealand Herald, Auckland, p. 6. 
Askey, P. (1995a, November 23). Peter Askey, Principal Environmental Engineer for Works Consultancy Ltd to the Programme Manager, Environment Waikato. 6041 51A, Volume 1, Waikato Regional Council, Hamilton. Unpublished.

Askey, P. (1995b, December 19). Peter Askey to Environment Waikato. 6041 51A, Volume 1, Waikato Regional Council, Hamilton. Unpublished.

Askey, P. (1996, July 25). Works Consultancy Ltd to Nehenehenui Regional Management Committee. 6041 51A, Volume 1, Waikato Regional Council, Hamilton. Unpublished.

Auckland and Waikato Fish and Game. (1997, March 20). Auckland/Waikato Fish \& Game to Environment Waikato. 6041 51A, Volume 1, Waikato Regional Council, Hamilton. Unpublished.

Bargh, M. (2016). Opportunities and Complexities for Māori and mana whenua Representation in Local Government. Political Science, 68(2), 143-160.

Bargh, M. (2018). Māori Political and Economic Recognition in a Diverse Economy. In D. Howard-Wagner, M. Bargh, \& I. Altamirano-Jiménez (Eds.), The Neoliberal State, Recognition and Indigenous Rights (1st ed., pp. 293-308). Canberra: ANU Press. https://doi.org/10.22459/CAEPR40. 07.2018.

Bell, A. (2018). A flawed Treaty Partner: The New Zealand State, Local Government and the Politics of Recognition. In D. Howard-Wagner, M. Bargh, \& I. Altamirano-Jimenez (Eds.), The Neoliberal State, Recognition and Indigenous Rights: New Paternalism to New Imaginings (pp. 77-92). Canberra: ANU Press.

Boyt, C. (2010, November 19). Email from Cliff Boyt. 6041 51A, Volume 4, Waikato Regional Council, Hamilton. Unpublished.

Boyt, C. (2012, May 16). Cliff Boyt to Waikato Regional Council. Document 2187740, Waikato Regional Council, Hamilton. Unpublished.

Broughton, D., (Te Aitanga-a-Hauiti, Taranaki, Ngā), McBreen, K., \& (Waitaha, Kāti Māmoe, Ngāi Tahu). (2015). Mātauranga Māori, tino rangatiratanga and the future of New Zealand science. Journal of the Royal Society of New Zealand, 45(2), 83-88.

Burton, L., \& Cocklin, C. (1996). Water Resource Management and Evironmental Policy Reform in New Zealand: Regionalism, Allocation, and Indigenous Relations. Colorado Journal of International Environmental Law and Policy, 7, 331.

Coombes, B., \& Hil, S. (2005). "Na whenua, na Tuhoe. Ko D.o.C. te partner"-Prospects for Comanagement of Te Urewera National Park. Society \& Natural Resources, 18(2), 135-152. 
Coulthard, G. S. (2007). Subjects of Empire: Indigenous Peoples and the 'Politics of Recognition' in Canada. Contemporary Political Theory, 6(4), 437-460.

Coulthard, G. S. (2014). Red Skin, White Masks: Rejecting the Colonial Politics of Recognition. Minneapolis: University of Minnesota Press.

Crow, S. K., Tipa, G. T., Booker, D. J., \& Nelson, K. D. (2018). Relationships between Maori Values and Streamflow: Tools for Incorporating Cultural Values Into Freshwater Management Decisions. New Zealand Journal of Marine and Freshwater Research, 52(4), 626-642.

Cunningham, M. (2014). The Environmental Management of the Waipa River and Its Tributaries. Case-Study Commissioned by the Waitangi Tribunal for Te Rohe Potae District Inquiry (Wai 898) (District Inquiry Research Report No. A150 (Wai 868_). Wellington: Waitangi Tribunal.

Department of Public Works. (1928). Removal of Gravel from Waipa River. ABKK W4 357889 Box 132. National Archives, Wellington. Unpublished. Dixon, J. (1937, February 27). Government Intervention. King Country Chronicle, p. 5.

Environment Waikato. (1996, July 31). Environment Waikato Memorandum. 6041 51A, Volume 1, Waikato Regional Council, Hamilton. Unpublished. Figueroa, R. M. (2001). Other Faces: Latinos and Environmental Justice. In L. Westra \& B. E. Lawson (Eds.), Faces of Environmental Racism: Confronting Issues of Global Justice (pp. 167-184). Lanham: Rowman \& Littlefield Publishers.

Finlay, G. P. (1923, May 4). King Country Tour. Auckland Star, Auckland. Retrieved from https://paperspast.natlib.govt.nz/newspapers/AS19230504. 2.80 ?query=nativitis.

Forster, M. (2016). Indigenous-Environmental-Autonomy-in-Aotearoa-newZealand. AlterNative: An International Journal of Indigenous Peoples, 12(3), 316-330.

Gott, J. (1916, June 21). Devonport Refuse Tip. Letter to Editor. NZ Herald, p. 5. Greensill, A. N. (2010). Inside the Resource Management Act: A Tainui Case Study. (Thesis). The University of Waikato. Retrieved 25 June 2019, from https://researchcommons.waikato.ac.nz/handle/10289/4922.

Harmsworth, G., Awatere, S., \& Robb, M. (2016). Indigenous Māori Values and Perspectives to Inform Freshwater Management in Aotearoa-New Zealand. Ecology and Society, 21(4), 9.

Hauauru Ki Uta Regional Management Committee. (2011, July 26). Submission of Hauauru Ki Uta Regional Management Committee. Documber Number 2018335. Waikato Regional Council, Waikato Regional Council Archives, Hamilton. Unpublished. 
Hayward, J. (2011). Mandatory MÄori Wards in Local Government: Active Crown Protection of MÄri Treaty Rights. Political Science, 63(2), 186-204.

Hopkins, D., Joly, T. L., Sykes, H., Waniandy, A., Grant, J., Gallagher, L., et al. (2019). "Learning Together": Braiding Indigenous and Western Knowledge Systems to Understand Freshwater Mussel Health in the Lower Athabasca Region of Alberta, Canada. Journal of Ethnobiology, 39(2), 315-336.

Howitt, R., \& Suchet-Pearson, S. (2006). Rethinking the Building Blocks: Ontological Pluralism and the Idea of 'Management'. Geografiska Annaler: Series B, Human Geography, 88(3), 323-335.

Jacobson, C., Matunga, H., Ross, H., \& Carter, R. W. (2016). Mainstreaming Indigenous Perspectives: 25 Years of New Zealand's Resource Management Act. Australasian Journal of Environmental Management, 88(4), 331-337.

James, P., \& Pawson, E. (1995). Contested Places: The Significance of the Montunui-Waitara Claim to the Waitangi Tribunal.AboriginalHistory, 19, 111. Jensen, W. (2011, July 26). Submission of Wayne Jensen. Document Number 2019051. Waikato Regional Council, Waikato Regional Council Archives, Hamilton. Unpublished.

Jones, C. (2016). New Treaty, New Tradition: Reconciling New Zealand and Maori Law. Toronto: University of British Columbia.

Knight, C. (2016). New Zealand's Rivers: An Environmental History. Christchurch: Canterbury University Press.

Knight, C. (2019). A Potted History of Freshwater Management in New Zealand. Policy Quarterly, 15(3). https://doi.org/10.26686/pq.v15i3.5681.

Kowhai Consulting Ltd. (2007). He Mahere Taiao: The Maniapoto Iwi Environmental Management Plan for Maniapoto Maori Trust Board. Otorohanga: Kowhai Consulting Ltd..

Kowhai Consulting Ltd, \& Ministry for the Environment. (2002). Te Purongo: Ngati Maniapoto State of the Environment Report: A Tribal Perspective. Otorohanga: Kowhai Consulting Ltd..

Lewis, N., Lewis, O., \& Underhill-Sem, Y. (2009). Filling Hollowed Out Spaces with Localised Meanings, Practices and Hope: Progressive Neoliberal Spaces in Te Rarawa. Asia Pacific Viewpoint, 50(2), 166-184.

Lowry, A., \& Simon-Kumar, R. (2017). The Paradoxes of Māori-State Inclusion: The Case Study of the Ōhiwa Harbour Strategy. Political Science, 69(3), 195-213.

McCormack, F. (2018). Indigenous Settlements and Market Environmentalism: An Untimely Coincidence? In D. Howard-Wagner, M. Bargh, \& I. Altamirano-Jiménez (Eds.), The Neoliberal State, Recognition and Indigenous Rights (Vol. 40, pp. 273-292). Canberra: ANU Press. 
Mead, H. M. (2016). Tikanga Maori (Revised Edition): Living by Maori Values. Wellington: Huia Publishers.

Moore, J. W. (2015). Capitalism in the Web of Life: Ecology and the Accumulation of Capital. Verso Books.

Morgan, T. K. K. B., \& Te Aho, L. (2013). Waikato Taniwharau: Prioritising Competing Needs in the Management of the Waikato River. In J. Daniels (Ed.), Advances in Environmental Research. New York: Nova Science Publishers.

Muru-Lanning, M. (2012). The Key Actors of Waikato River Co-governance: Situational Analysis at Work. AlterNative: An International Journal of Indigenous Peoples, 8(2), 128-136.

Mutu, M. (2018). Behind the Smoke and Mirrors of the Treaty of Waitangi Claims Settlement Process in New Zealand: No Prospect for Justice and Reconciliation for Māori Without Constitutional Transformation. Journal of Global Ethics, 14(2), 208-221. https://doi.org/10.1080/17449626.2018.1507003.

Mutu, M. (2019). The Treaty Claims Settlement Process in New Zealand and Its Impact on Māori. Land, 8(10), 152. https://doi.org/10.3390/land8100152.

New Zealand Government. (1956a). Health Act. Retrieved 7 January 2020, from http://www.legislation.govt.nz/act/public/1956/0065/latest/whole.html.

New Zealand Government. (1956b). Waikato Valley Authority Act. Retrieved 22 January 2020, from http://www.nzlii.org/nz/legis/hist_act/ wvaa19561956n104320/.

New Zealand Parliament. (1953). Waters Pollution Act. Retrieved 22 January 2020, from http://www.nzlii.org/nz/legis/hist_act/wpa19531953n104253/.

New Zealand Parliament. (1967). Water and Soil Conservation Act., Pub.

L. No. 135. Retrieved 16 June 2020, from http://www.nzlii.org/nz/legis/ hist_act/wasca19671967n135320/.

New Zealand Parliament. (1991). Resource Management Act. Retrieved 16 June 2020, from http://www.legislation.govt.nz/act/public/1991/0069/223.0/ DLM230265.html.

New Zealand Parliament. (2002). Local Government Act. Retrieved 16 June 2020, from http://www.legislation.govt.nz/act/public/2002/0084/167.0/ DLM170873.html.

Parsons, M., Nalau, J., \& Fisher, K. (2017). Alternative Perspectives on Sustainability: Indigenous Knowledge and Methodologies. Challenges in Sustainability, 5(1), 7-14.

Pauling, C., \& Ataria, J. (2010). Tiaki Para: A Study of Ngāi Tahu Values and Issues Regarding Waste. Lincoln: Manaaki Whenua Press. 
Pollution Advisory Council. (1956). Report on Pollution in the Waikato River Basin. Wellington: Pollution Advisory Council.

Pulido, L. (1998). Environmentalism and Economic Justice: Two Chicano Struggles in the Southwest. Senior Managing Editor, 5(2), 70.

Pulido, L. (2015). Geographies of Race and Ethnicity 1: White Supremacy vs White Privilege in Environmental Racism Research. Progress in Human Geography, 39(6), 809-817.

Pulido, L. (2016). Environmental Racism. In International Encyclopedia of Geography: People, the Earth, Environment and Technology: People, the Earth, Environment and Technology (pp. 1-13). Hoboken: Wiley Online Library.

Pulido, L. (2017a). Evolving Racial Formations and the Environmental Justice Movement. In R. B. Holifield, J. Chakraborty, \& G. P. Walker (Eds.), The Routledge Handbook of Environmental Justice. London and New York: Routledge and Taylor \& Francis Group.

Pulido, L. (2017b). Geographies of Race and Ethnicity II: Environmental Racism, Racial Capitalism and State-Sanctioned Violence. Progress in Human Geography, 41(4), 524-533.

Pulido, L. (2017c). Geographies of Race and Ethnicity III: Settler Colonialism and Nonnative People of Color. Progress in Human Geography, 42(2), 309-318. Pulido, L., \& Peña, D. (1998). Environmentalism and Positionality: The Early Pesticide Campaign of the United Farm Workers' Organizing Committee, 1965-1971. Race, Gender \& Class, 6, 33-50.

Pulido, L., Kohl, E., \& Cotton, N.-M. (2016). State Regulation and Environmental Justice: The Need for Strategy Reassessment. Capitalism Nature Socialism, 27(2), 12-31. https://doi.org/10.1080/1045575 2.2016.1146782.

Robinson, H. (2011). Te taha tin ana: maori health and the crown in te rohe potae inquiry district, 1840 to 1990 (A Report for Rohe Potae District Inquiry (Wai 898) No. A31). Wellington: Waitangi Tribunal.

Ryks, J., Wythe, J., Baldwin, S., \& Kennedy, N. (2010). The Teeth of the Taniwha: Māori Representation and Participation in Local Government. Planning Quarterly, 177, 39-42.

Schlosberg, D. (2003). The Justice of Environmental Justice: Reconciling Equity, Recognition, and Participation in a Political Movement. Moral and Political Reasoning in Environmental Practice, 77, 106.

Schlosberg, D. (2013). Theorising Environmental Justice: The Expanding Sphere of a Discourse. Environmental Politics, 22(1), 37-55. 
Stammers, J. (2008, April 15-16). Report on Discharge of Sewage to Water. 60 41 51A, Volume 3, Hamilton: Waikato Regional Council. Unpublished.

Sullivan, W. A. (1998). Changing the Face of Eden: A History of Auckland Acclimatisation Societies, 1861-1990. Hamilton: Auckland/Waikato Fish \& Game Council.

Taonga, N. Z. M. for C. and H. T. M. (2020). Population and Society. Te Ara Encyclopedia of New Zealand. Web Page, Ministry for Culture and Heritage Te Manatu Taonga. Retrieved 2 June 2020, from https://teara.govt.nz/en/ king-country-region/page-7.

Taylor, A., \& Te Taha Māori. (1986, March). The Importance of the Sea and the Waterways to the Maori, and Why Outfalls are Unacceptable as Effluent Treatment. Nature Conservation Council Newsletter, p. 60.

Te Aho, L. (2015). The Waikato River Settlement: Exploring a Model for Co-management and Protection of Natural and Cultural Resources. Ka Hula Ao Center for Excellence in Native Hawaiian Law, Richardson School of Law. Retrieved 6 January 2019, from https://researchcommons.waikato.ac.nz/ handle/10289/10414.

Thompson-Fawcett, M., Ruru, J., \& Tipa, G. (2017). Indigenous Resource Management Plans: Transporting Non-Indigenous People into the Indigenous World. Planning Practice \& Research, 32(3), 259-273.

Tipa, G., Nelson, K., Home, M., \& Tipa, M. (2016). Policy Responses to the Identification by Maori of Flows Necessary to Maintain Their Cultural Values. 37th Hydrology \& Water Resources Symposium 2016: Water, Infrastructure and the Environment, p. 552.

Tribunal, W. (1993). The Waitangi Tribunal and the Motunui-Waitara Claim. Wellington: Waitangi Tribunal.

Unknown Author. (1897, January 27). Is Typhoid Preventible?. Wanganui Chronicle, p. 2.

Unknown Author. (1900). Duck Shooting in New Zealand. New Zealand Illustrated Magazine, III, p. 61.

Unknown Author. (1916, June 14). Health of the Borough. King Country Chronicle, p. 5.

Unknown Author. (1926, July 30). Death from Typhoid. New Zealand Herald, p. 10.

Unknown Author. (1935, August 24). New Trout Hatchery. Waikato Independent. Retrieved 5 June 2019, from https://paperspast.natlib.govt.nz/newspapers/ WAIKIN 19350824.2 .4 ? query=flood $\% 20$ waipa $\% 20$ river $\&$ sort_ by $=$ byDA\&items_per_page $=100 \&$ page $=6 \&$ snippet $=$ true \&title $=K W E, N Z$, 
NZH,PWT,ROTWKG,TO,ACNZC,AKTIM,NZHAG,ALG,AS,DSC,KC C,OG,PAKIOM,TAN,THA,THS, WAIGUS, WAIKIN,WHDT,WT,MAT REC,TGMR\&type=ARTICLE.

Unknown Author. (1936, September 11). High Death Rate. New Zealand Herald, p. 12.

Unknown Author. (1937, October 28). Maoris and Typhoid. Waikato Independent, p. 5.

Unknown Author. (1957). Minutes of a Meeting of the Waikato Valley Authority, 5 August, 1957, Series 113 60/1, Waikato Regional Council Archives. Hamilton: Waikato Regional Council. Unpublished.

Unknown Author. (1966a, January 11). Application for Registration of an Outfall and Permit Discharge Wastes Into Classified Waters. 6041 51A, Volume 1. Hamilton: Waikato Regional Council. Unpublished.

Unknown Author. (1966b, May 24). Minutes of Otorohanga Oxidation Ponds Working Party Meeting. 6041 51A, Volume 1. Hamilton: Waikato Regional Council. Unpublished.

Unknown Author. (1967, June 29). Temporary Permit No. 434/209/T. 6041 51A, Volume 1. Hamilton: Waikato Regional Council. Unpublished.

Unknown Author. (1968, March 1). Temporary Permit No. 434/209/1T. 6041 51A, Volume 1. Hamilton: Waikato Regional Council. Unpublished.

Unknown Author. (1970, May 2). Temporary Permit No. 434/726, 6041 51A, Volume 1, Waikato Regional Council; Inspector of Health to the Medical Officer of Health. 6041 51A, Volume 1. Hamilton: Waikato Regional Council. Unpublished.

Unknown Author. (1974a, May 6). Secretary of the Waikato Valley Authority to the Otorohanga County Clerk. 6041 51A, Volume 1. Hamilton: Waikato Regional Council. Unpublished.

Unknown Author. (1974b, May 27). Otorohanga County Engineer to the Secretary of the Waikato Valley Authority. 6041 51A, Volume 1. Hamilton: Waikato Regional Council. Unpublished.

Unknown Author. (1974c, July 23). Notice of Objection. 6041 51A, Volume 1. Hamilton: Waikato Regional Council. Unpublished.

Unknown Author. (1974d, October 10). Water Right No. 2594. 6041 51A, Volume 1. Hamilton: Waikato Regional Council. Unpublished.

Unknown Author. (1975a, July 24). Water Right Application. 6041 51A, Volume 1. Hamilton: Waikato Regional Council. Unpublished.

Unknown Author. (1975b, October 29). Water Right No. 2787. 6041 51A, Volume 1. Hamilton: Waikato Regional Council. Unpublished. 
Unknown Author. (1990, September 28). Manager Resource Monitoring, Environment Waikato, to Otorohanga District Council. 6041 51A, Volume 1. Hamilton: Waikato Regional Council. Unpublished.

Unknown Author. (1993, March). Internal Report-Resource Consent Monitoring. 6041 51A, Volume 1. Hamilton: Waikato Regional Council. Unpublished.

Unknown Author. (1995a, February 13). Manager of Resource Use Monitoring, Environment Waikato, to Otorohanga District Council. 6041 51A, Volume 1. Hamilton: Waikato Regional Council. Unpublished.

Unknown Author. (1995b, September 15). Inquiries Officer, Environment Waikato, to Otorohanga District Council. 6041 51A, Volume 1. Hamilton: Waikato Regional Council. Unpublished.

Unknown Author. (1995c, August 10, 15). File Notes. 6041 51A, Volume 1, Hamilton: Waikato Regional Council. Unpublished.

Unknown Author. (1995d, December 6). Programme Manager of Energy and Ultilies, Environment Waikato to the Chief Executive Officer of Otorohanga District Council. 6041 51A, Volume 1. Hamilton: Waikato Regional Council. Unpublished.

Unknown Author. (1995e, October 11). Minutes of Meeting Held with the Nehenehenui Regional Management Committee. 6041 51A, Volume 1. Hamilton: Waikato Regional Council. Unpublished.

Unknown Author. (1995f, October 12). Minutes of Otorohanga Oxidation Ponds Working Party Meeting. 6041 51A, Volume 1. Hamilton: Waikato Regional Council. Unpublished.

Unknown Author. (1996a, July 16). Secretary of Te Nehenehenui Regional Management Committee to Works Consultancy Ltd. 6041 51A, Volume 1. Hamilton: Waikato Regional Council. Unpublished.

Unknown Author. (1996b, September 10). Minutes of the meeting held with Te Mauri o Maniapoto. 6041 51A, Volume 1. Hamilton: Waikato Regional Council. Unpublished.

Unknown Author. (1998). Attachment-Submission in Opposition. Series 60 61 24A, Volume 3. Hamilton: Waikato Regional Council. Unpublished. Unknown Author. (1999a, March 23). Minutes of Meeting Held at Te Kuiti. Series 6061 24A, Volume 3. Hamilton: Waikato Regional Council. Unknown Author.

Unknown Author. (1999b). Submissions Folder, Series 6061 24A Volume 3. Hamilton: Waikato Regional Council. Unpublished.

Unknown Author. (2008, October 29). Consent Compliance Audit Report. 60 41 51A, Volume 3. Hamilton: Waikato Regional Council. Unpublished. 
Unknown Author. (2009a, May 15). Resource Consent Monitoring Report. 60 41 51A, Volume 3. Hamilton: Waikato Regional Council. Unpublished.

Unknown Author. (2009b, October 1). Email from the Resource Officer, Environment Waikato, to Jon Stammers. 6041 51A, Volume 4. Hamilton: Waikato Regional Council. Unpublished.

Unknown Author. (2009c, October 20). Application for s127 change to Consent-Evaluation Report. 6041 51A, Volume 4. Hamilton: Waikato Regional Council. Unpublished.

Unknown Author. (2010a, October 19). Resource Officer, Environment Waikato, to Otorohanga District Council. 6041 51A, Volume 4. Hamilton: Waikato Regional Council. Unpublished.

Unknown Author. (2010b, September 28). Consent Compliance Audit Report. 6041 51A, Volume 4. Hamilton: Waikato Regional Council. Unpublished.

Unknown Author. (2010c, May). Resource Consent Monitoring Report. 6041 51A, Volume 4. Hamilton: Waikato Regional Council. Unpublished.

Unknown Author. (2011a, October). Resource Consents Application and Assessment of Effects on the Environment: Otorohanga Wastewater Treatment Plant-Resource Consents Project, pp. 65-73. Document 2077260. Hamilton: Waikato Regional Council. Unpublished.

Unknown Author. (2011b, March 10). Otorohanga Wastewater Treatment Plant-Resource Consents Project, pp. 4-5, 10. 6041 51A, Volume 5. Hamilton: Waikato Regional Council. Unpublished.

Unknown Author. (2011c, October). Resource Consents Application and Assessment of Effects on the Environment: Otorohanga Wastewater Treatment Plant-Resource Consents Project, Appendix K Consultation Plan, pp. 14-16. Document 2077260, 6041 51A, Volume 5. Hamilton: Waikato Regional Council. Unpublished.

Unknown Author. (2011d, October). Resource Consents Application and Assessment of Effects on the Environment: Otorohanga Wastewater Treatment Plant-Resource Consents Project, Appendix J Cultural Impact Assessment Report, pp. 3, 11. Documber 2077260. Hamilton: Waikato Regional Council. Unpublished.

Unknown Author. (2012a, June). Resource Consent 953619 Monitoring Report. 6041 51A, Volume 5. Hamilton: Waikato Regional Council. Unpublished.

Unknown Author. (2012b, August 17). Consent Compliance Audit Report. 60 41 51A, Volume 5. Hamilton: Waikato Regional Council. Unpublished.

Unknown Author. (2012c, August 23). Chief Executive of Otorohanga District Council to Waikato Regional Council. 6041 51A, Volume 5. Hamilton: Waikato Regional Council. Unpublished. 
Unknown Author. (2012d, August 21). Email from the Senior Resource Officer, Waikato Regional Council, to Cliff and Pat Boyt. 6041 51A, Volume 5. Hamilton: Waikato Regional Council. Unpublished.

Unknown Author. (2012e, November 2). Report of the Waikato Regional Council. Documber 2292779. Hamilton: Waikato Regional Council. Unpublished.

Walker, G. (2009). Beyond Distribution and Proximity: Exploring the Multiple Spatialities of Environmental Justice. Antipode, 41(4), 614-636.

Wheen, N. R., \& Hayward, J. (2012). Treaty of Waitangi Settlements. Wellington: Bridget Williams Books.

Whyte, K. P. (2018). Settler Colonialism, Ecology, and Environmental Injustice. Environment and Society, 9(1), 125-144.

Wood, G. E. (1950). The New Zealand Official Year-Book, 1947-1949. Wellington: Census and Statistics Department. Retrieved 2 June 2020, from https://www3.stats.govt.nz/New_Zealand_Official_Yearbooks/1947-49/ NZOYB_1947-49.html\#idsect1_1_57826.

Works Consulting Ltd. (1995, December 19). Works Consulting Ltd to Te Porerau Joseph, Te Mauri o Maniapoto. 6041 51A, Volume 1. Hamilton: Waikato Regional Council. Unpublished.

Open Access This chapter is licensed under the terms of the Creative Commons Attribution 4.0 International License (http://creativecommons.org/licenses/ by/4.0/), which permits use, sharing, adaptation, distribution and reproduction in any medium or format, as long as you give appropriate credit to the original author(s) and the source, provide a link to the Creative Commons licence and indicate if changes were made.

The images or other third party material in this chapter are included in the chapter's Creative Commons licence, unless indicated otherwise in a credit line to the material. If material is not included in the chapter's Creative Commons licence and your intended use is not permitted by statutory regulation or exceeds the permitted use, you will need to obtain permission directly from the copyright holder.

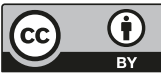

